\title{
Impacto das Novas Ideias na Dogmática do Direito de Propriedade. \\ A Multiplicidade Dominial.
}

\author{
Marcos Alcino de Azevedo Torres ${ }^{1}$
}

Resumo: O impacto das novas idéias na dogmática do direito de propriedade, com destaque à existência de um conceito único, abrangente de todas as espécies de propriedade. Existe m diversos direitos se propriedade ou somente um.

Palavras-chave: propriedade - espécies de direito de propriedade

Abstract: The impact of new ideas in the dogmatic property rights, especially the existence of a unívoc, comprehensive concept of all kinds of property. There are $\mathrm{m}$ different property rights or only one.

Keywords: property - species of property right

1 Desembargador do Tribunal de Justiça do Estado do Rio de Janeiro. Professor Adjunto de Direito Civil da Faculdade de Direito da Universidade do Estado do Rio de Janeiro - UERJ. 


\section{1 - Introdução.}

O tema de nosso estudo neste ensaio será o impacto das novas idéias na dogmática do direito de propriedade, em especial destaque quanto à existência de um conceito unívoco, abrangente de todas as espécies de propriedade ou se há necessidade de reconhecermos a existência de diversos direitos de propriedade conforme a natureza e a titularidade do bem que é seu objeto. O problema é: há só um direito de propriedade ou diversos direitos com reflexos no conteúdo e no seu exercício?

A questão, talvez por sua especificidade, não tem sido objeto de inclusão em manuais e até mesmo em artigos que analisam o direito de propriedade, salvo raras exceções. ${ }^{2}$

No entanto, todos sabemos que o direito de propriedade sofreu, como de regra acontece com todos os institutos jurídicos ao longo do tempo, influencias das idéias de cada tempo, do momento histórico e cultural de cada nação, sendo que nos últimos 200 anos podemos destacar três momentos marcantes na caracterização da propriedade: a propriedade feudal; a passagem da propriedade feudal para a propriedade democratizada após a revolução francesa, estribada em ideais liberais, considerada propriedade-burguesa, sob domínio pleno e ilimitado de seu titular e o terceiro, ainda em conformação, o reconhecimento de uma propriedade funcionalizada, como um instituto voltado para o atendimento do homem como pessoa e não simplesmente como o bem componente de seu patrimônio ou como riqueza particular.

Por outro lado, não há dúvida de que o direito de propriedade sofra a influencia do regime econômico dominante ${ }^{3}$, seja na sua configuração seja na sua conformação,

2 TEPEDINO, Gustavo. Contornos Constitucionais da Propriedade Privada. In: Temas de Direito Civil. Rio de Janeiro: Renovar, 1999, p. 267-291. LOUREIRO, Eduardo Francisco. A Propriedade como Relação Jurídica Complexa. Rio de Janeiro: Renovar, 2003, p. 53-61; VARELA, Laura Beck. Das Propriedades à Propriedade: construção de um direito. p. 730-762. VARELA, Laura B. e LUDWIG, Marcos de C. Da Propriedade às Propriedades: Função Social e Reconstrução de um Direito. p. 763788 ambos in $A$ Reconstrução do Direito Privado. Org. Judith Martins-Costa. Editora Revista dos Tribunais, 2002.

3 Cf. registro de J. Gilissen na Rússia, p.ex., depois da tomada do poder pela Revolução em novembro de 1917, uma das primeiras medidas adotadas foi um decreto que anulou, sem qualquer indenização, a propriedade latifundiária e a partir de fevereiro de 1918 a terra foi declarada propriedade do Estado, tal como as fábricas, os bancos, os imóveis, etc. (GILISSEN, John. 
"distendendo ou adelgaçando ao sabor de sua evolução"4, mas parece que não há regime político sem propriedade ao ponto de Karl Marx afirmar que não é possível pensar em nenhuma sociedade, "donde no exista ninguna forma de propriedad: esto es tautologia". 5 E mais, segundo Engels todas as revoluções é contra ou a favor de um tipo de propriedade e um tipo de propriedade não pode ser protegido sem que lese o outro, sendo que na "grande Revolução Francesa, a propriedade feudal foi sacrificada para que se salvasse a propriedade burguesa"6. Até mesmo paises como a China e Cuba que resistem, em razão do sistema econômico e político que adotam ao reconhecimento do direito de propriedade como um bem privado do cidadão conforme sejam eles de produção e de consumo, têm gradativamente cedido aos seus encantos admitindo em relação a certos bens a propriedade privada, inclusive do solo, visando incentivar a produção devido a escassez, com maior ganho para trabalhador individualmente e também para a coletividade como um todo, num viés capitalista, como noticiou a grande imprensa num passado próximo.

Parece ter razão Raísa Jálfina em afirmar que as formas de propriedade caracterizam todo o regime da sociedade, sua estrutura classista, seu regime político e o processo de seu desenvolvimento social, por isso a propriedade é uma das instituições mais importantes de cada sistema jurídico e como categoria econômica, a propriedade existe em todas as etapas de produção social, mas como categoria jurídica, somente se configura e se rege na sociedade organizada em Estado, pois este é que assegura a proteção de todas as relações de propriedade existente na sua sociedade na direção coincidente com os interesses da classe dominante. ${ }^{7}$

Introdução Histórica ao Direito. Trad. A.M.Hespanha. Lisboa: Fundação Calouste Gulbenkian, 1979, p. 647).

4 CHAMOUN, Ebert. Instituições de Direito Romano, 3. ed., Rio de Janeiro: Revista Forense, 1957, p.233.

5 MARX, karl. De los manuscritos econômicos de 1857-1858. T. 12, p. 714, apud JÁLFINA, Raísa. El Derecho de Propriedad Del Estado em la Urss. Trad. Federico Pita. Moscou: Editorial Pregresso, 1981 , p. 9.

${ }^{6}$ ENGELS, Friedrich. A Origem da Família, da Propriedade Privada e do Estado. São Paulo: Global Ed., 1984, p. 161.

7 JÁLFINA, Raísa. El Derecho de Propriedad Del Estado em la Urss. Trad. Federico Pita. Moscou: Editorial Pregresso, 1981, p. 9. 
É interessante observar a crítica que a Comissão de Juristas que elaborou no século passado o Projeto de Código Civil do México, no distante ano de 1928, fez ao direito de propriedade como estava regulado no código civil que se pretendia revogar:

Nuestro actual Código Civil, producto de las necesidades económicas y jurídicas de otras épocas; elaborado cuando dominaba en el campo económico la pequeña industria y en el orden jurídico en exagerado individualismo, se ha vuelto incapaz de regir las nuevas necesidades sentidas y las relaciones que, aunque de carácter privado, se hallam fuertemente influenciadas por las diarias conquistas de la gran industria y por los progresivos triunfos del principio de solidaridad.

Para transformar un Código Civil, en que predomina el criterio individualista, en un Código Privado Social, es preciso reformarlo substancialmente, derogando todo cuanto favorece exclusivamente el interés particular con perjuicio de la colectividad, e introduciendo nuevas disposiciones que se armonicen con el concepto de solidaridad. $^{8}$

A propriedade é um dos fenômenos sociais que ao mesmo tempo é justificadora da existência da liberdade do homem e justificadora da pior instituição que o passado registra e que em alguns lugares ainda se pratica: a escravidão, caracterizada pela exploração de um ser a outro seu semelhante.

Por isso, falar do direito de propriedade ou em propriedade, ${ }^{9}$ direito real máximo, não é uma tarefa muito fácil apesar de tudo que tem sido dito, por ser um tema que sempre provocou, ao longo das épocas, e ainda, por certo, há de provocar, grandes debates e transformações na evolução do ser humano, por isso, é um tema que interessa, devido à sua importância para a sociedade, a historiadores, filósofos, sociólogos, economistas, políticos e juristas, procurando todos fixar-lhe "um conceito, determinar-lhe a origem, caracterizar-lhe os elementos, acompanhar-lhe a evolução, justificá-la ou combatê-la”. É assim um tema, que

\footnotetext{
${ }^{8}$ MÉXICO. Código Civil, 37. ed, México: Editorial Porrua, S. A., 1974, p. 8, grifos nossos.

${ }^{9} \mathrm{~A}$ expressão propriedade, conforme registro de Oliveira Ascensão, é tomada em vários sentidos: ora, como todos os direitos adquiridos, ora como todos os direitos patrimoniais, ora como todos os direitos reais, ora com um direito real especifico (é o sentido técnico da expressão) e ora como objeto desse direito real. ASCENSÃO, José de Oliveira. Direito Civil. Reais. 4. ed., Coimbra Editora Ltda, 1987, p. 382. No mesmo sentido WOLFF, Martín. Derecho de Cosas. Trad. José Puig Brutau, 2. ed, Barcelona: Bosch, Casa Editorial, s/d, p. 287-288. Lafayette assinala que "direito de propriedade em sentido genérico, abrange todos os direitos que formam nosso patrimônio". PEREIRA, Lafayette R. Direito das Cousas, p. 97. Por vezes aqui e ali se toma a expressão propriedade, como direito de propriedade.
} 
desperta a atenção de todos, inclusive de leigos. ${ }^{10}$ Para historiadores, como assinala Paolo Grossi a propriedade deve ser considerada somente um artifício verbal para indicar a solução histórica que um determinado ordenamento dá a questão do vinculo mais intenso entre um sujeito e um bem ou dito de outro modo: a resposta à "questão central sobre a consistência mínima do 'meu' jurídico. ${ }^{11}$

Fonte de riqueza e de poder, inviolável e sagrada, essencial e natural segundo a Declaração da Virginia de 1776, natural e imprescritível segundo a Declaração dos Direitos do Homem e do Cidadão de 1789 na França ${ }^{12}$, odiada por uns, acusada de todos os males, amada, cobiçada por outros, a propriedade ou o direito de propriedade, é um tema eriçado, não importa a conformação que tome, a questão envolve sempre seu uso, distribuição, enfim, o acesso aos bens que se podem tornar próprios ou que possam permitir uma melhor condição de vida para o cidadão, não importa o regime político em que viva, o que importa é que a cada tempo vem-se reinterpretando à propriedade.

Richard Pipes salienta que a propriedade pode ser estudada a partir de duas perspectivas: como conceito e como instituição, com resultados bem diferentes, tendo a propriedade, gozado ao longo da história, de uma reputação ambígua, sendo às vezes identificada como propriedade e liberdade e outras vezes com corrupção moral, injustiça social e guerra e mesmo os pensadores favoráveis à propriedade a consideram, na melhor das hipóteses, um mal inevitável e remata:

\begin{abstract}
"A história de todas as sociedades, por outro lado, da mais primitiva à mais avançada, revela a universalidade do direito à propriedade e da falência de todas as tentativas de se criar uma comunidade sem propriedade, tanto voluntariamente como pela força. Nesse caso, portanto, existe um disparidade excepcionalmente ampla entre o que a humanidade pensa que quer e o que, julgando por sua ações ela realmente prefere." 13
\end{abstract}

O reconhecimento de que algo é próprio, do meu, do teu, característica do direito de propriedade privada influencia o conceito de justiça em Justiniano: "Justitia est

10 PEREIRA, Caio M. da S. Instituições de Direito Civil. Direitos Reais. v. IV, Rio Janeiro:Forense, 2003, Carlos Edison do R. Monteiro [atual.], p. 81.

11 GROSSI, Paolo. História da Propriedade e outros ensaios. Trad. Luiz E. Fritoli e Ricardo M. Fonseca. Rio de Janeiro: Renovar, 2006, p. 5.

$12 \mathrm{KICH}$, Bruno C. A Propriedade na Ordem Jurídica, Econômica e Ideológica. Porto Alegre: Sergio Antonio Fabris Editor, 2004, p. 18-19.

13 PIPES, Richard, ob cit. p. 23. 
constant et perpetue voluntas jus suun cuique tribuend"14. Hobbes assinala que "onde não há o seu, isto é, não há propriedade, não pode haver injustiça."15 Proudhon analisando situação proprietário ao tempo da Revolução Francesa e o desejo do povo, escreveu:

El pueblo quiso que la condición de propietario fuese igual para todos: que cada uno pudiera gozar y disponer libremente de sus bienes, de sus rentas, del producto de su trabajo y de su industria. El pueblo no inventó la propiedad; pero como no existía para él del mismo modo que para los nobles y los clérigos, decretó la uniformidad des este derecho". "Las odiosas formas de la propiedad, la servidumbre personal, la mano muerta, los vínculos, la exclusión de los empleos, han desaparecido; el modo de disfrutarla ha sido modificado, pero la esencia de la institución subsiste. Hubo progresos en la atribución, en el reconocimiento del derecho, pero no hubo revolución en el derecho mismo." 16

É a distribuição da propriedade que impulsiona a construção das teorias da justiça. Rawls salienta que deve existir um setor de distribuição, cuja tarefa é preservar uma justiça aproximativa das partes a serem distribuídas por meio de taxação e de ajustes que se fizerem necessários no direito de propriedade. O objetivo desta taxação não é a arrecadação, mas sim corrigir, gradual e continuamente, a distribuição da riqueza, impedindo a concentração de poder. ${ }^{17}$

Não podemos, contudo, ignorar as ponderações do pranteado Caio Mário da S.

Pereira, na seguinte passagem de seu manual:

Muito erra o profissional que põe os olhos no direito positivo e supõe que os lineamentos legais do instituto constituem a cristalização dos princípios em termos permanentes, ou que o estágio atual da propriedade é a derradeira, definitiva fase de seu desenvolvimento. Ao revés, evolve sempre, modifica-se ao sabor das injunções econômicas, políticas, sociais e religiosas. Nem se pode falar, a rigor, que a estrutura jurídica da propriedade, tal como se reflete em nosso Código, é a determinação de sua realidade sociológica, pois que aos nossos olhos e sem que alguém possa impedi-lo, ela está passando por transformações tão substanciais quanto aquelas que caracterizaram a criação da propriedade individual, ou que inspiraram a sua concepção feudal. ${ }^{18}$

Daí porque, antes de examinarmos a questão central deste ensaio: a multiplicidade dominial, recordaremos alguns aspectos do direito de propriedade.

14 Instituições de Justiniano. Livro 1 T. F. I. n.1, Curitiba: Tribunais do Brasil Editora Ltda., 1979.

15 MALMESBURY, Thomas Hobbes. Leviatã. Trad. João Paulo Monteiro e Maria B. Nizza da Silva. São Paulo: Editor Victor Civita, p. 86.

16 PROUDHON, Pedro Jose. Que es la Propriedad? . Trad. A. Gómez Pinilha. Buenos Aires: Editorial Proyección S.R.L. 1970, p. 40, grifos nossos.

17 RAWLS, John. Uma Teoria da Justiça. Trad. Almirio Pisetta e Lenita M.R. Esteves. São Paulo: Martins Fontes, 1997, p. 306.

18 Idem, Ibidem, p. 64. 


\section{2 - Breve escorço histórico}

Quando se pensa ou se faz um cotejo histórico não se pode olvidar da ponderação de Linhares de Lacerda de que "a noticia histórica dos acontecimentos do passado mais antigo, não podia ter chegado até nós escoimada de erros, porque a veiculação das ocorrências em relatos verbais e a duvidosa fidelidade dos cronistas à verdade dos fatos, povoou de fantasia os episódios cuja memória veio ao conhecimento dos historiadores modernos" ${ }^{\prime 19}$ e ainda que se disponha a uma pesquisa com um certo rigor cientifico dos dados históricos existentes, para deles extrairmos consequiências jurídicas, não devemos prescindir do emprego do método puramente lógico, para lograr a mais perfeita aproximação da verdade. ${ }^{20}$

Com este espírito lógico é possível supor que desde os primórdios da civilização o homem busque a satisfação de suas necessidades vitais ou não, nos bens existentes na natureza, algumas vezes satisfazendo necessidades físicas temporárias (p.ex. alimentação), outras vezes, necessidades físicas duradouras (p.ex. habitação). Tais necessidades fazem parte de seu instinto de sobrevivência e atendimento delas se dá, num momento embrionário de existência através de dois institutos básicos na cultura humana e que são normalmente confrontados: a posse e a propriedade. É através do apossamento, seja tal ação interpretada como posse ou como propriedade, seja temporária ou duradoura esta atuação de apossamento, que melhor se identificaria como titularidade. A Terra com suas riquezas naturais ou construídas é o maior bem de produção.

Neste contexto, a luta em busca de espaço para abrigo e sobrevivência não é nova e nem só nossa, mas remonta a um passado longínquo e se agrava à medida que os bens vão se escasseando ou à medida que os sistemas políticos permitam a concentração de grande quantitativo de bens nas mãos de poucos e em detrimentos de muitos.

19 LACERDA, M.Linhares de. Tratado das Terras do Brasil. Vol 1. Rio de Janeiro: Editora Alba Ltda, 1960, p. 7.

20 Idem, p. 8. 
De uma forma ou de outra, o homem se apossa das coisas para consumi-las, para utilizá-las ou para tê-las para si, ${ }^{21}$ temporariamente ou em caráter duradouro até que pela coisa se desinteresse, tudo conforme permita o sistema político em que esteja inserido, surgindo o direito de propriedade privada ou coletiva ou ainda, o desejo de possuir com certas prerrogativas ou com exclusividade, como observou Clóvis Beviláqua:

\begin{abstract}
"Os homens primitivos, naturalmente, se consideravam senhores daquilo de que se apoderavam, para satisfazer as próprias necessidades, pois que até em animais se observa esse sentimento. Mas sobre as coisas móveis de uso, e não destinadas ao consumo imediato, como armas e instrumentos de caça e pesca, é que já se manifesta uma projeção da personalidade, sobre o mundo externo, ligando o objeto ao sujeito. O solo ocupado não pode ainda ter caráter individual; a relação entre ele e a pessoa é posse econômica da coletividade, porque somente esta pode, eficazmente, defendê-la." 22
\end{abstract}

Em outra passagem, o mesmo autor, afirma que, quando a inteligência intervém orientada pelos fatos, com a idéia de previdência, o ato de apropriação começa a adquirir estabilidade, segurança e duração. ${ }^{23}$

Não é difícil imaginar que somente após o homem ter construído um mínimo de organização social e jurídica é que se pode reconhecer a existência de um direito com a conotação que nos foi legada com o nome de propriedade privada, haja vista que fora desta consciência social e jurídica, o respeito ao que é de cada um só se daria pela força ou pelo desinteresse em razão de um desvalor (econômico ou social) da coisa apossada. ${ }^{24}$

Neste contexto, pode-se supor que o instituto da posse, que não demanda organização jurídica para seu reconhecimento em razão de sua conotação fática e sua admissão natural por qualquer ser que tem um mínimo de inteligência, teria surgido primeiro do que o instituto da propriedade. Não se pode, no entanto, ignorar a observação de

\footnotetext{
21 Interessante observar que a atitude de possuir, de achar-se possuidor ou proprietário, conforme o nome que o observador queira dar, independente de idade, sanidade ou qualquer outro elemento, como pode se observar nas crianças, ainda em tenra idade e naqueles que a cultura jurídica considera como incapazes. Daí é de ser ressaltada a redação da primeira parte do art. 443 do C.C. Espanhol: "los menores y los incapacitados pueden adquirir la posesión de las cosas; pero necesitan de la asistencia de sus representantes legítimos para usar de los derechos que de la posesión nascan a su favor."

22 BEVILAQUA, Clovis. Direito das Coisas. 4. ed., vol. I. Rio de Janeiro: Forense. 1956, p. 96-97.

23 Idem. O Conceito de Propriedade. Rev. de Direito Público. Vol. II. Rio de Janeiro: Freitas Bastos Ed., 1940, p. 6.

${ }^{24}$ Neste tempo, ainda não se havia firmado a idéia de KANT do "meu jurídico ou meu direito (meum iuris)", ao qual está ligado o sujeito e "que o uso que um outro poderia fazer dele sem o meu consentimento me prejudicaria". Apud BOBBIO, Norberto. Direito e Estado no Pensamento de E. Kant. 2. ed. Edurb, 1992, p. 95.
} 
Washington de B. Monteiro, que a fase pré-histórica do direito de propriedade é um ponto "obscuro da história do direito e sobre o qual não foi dita a ultima palavra". ${ }^{25}$ No mesmo sentido se posicionou Serpa Lopes. ${ }^{26}$

\section{1 - Modelo inicial}

É costume ver-se nos autores, apesar de divergências quanto a ordem e quanto a identificação do modelo, que a evolução do direito de propriedade, teria passado por sistemas diversos. Marnoco Souza sustenta a seguinte ordem: propriedade coletiva; propriedade individual e do predomínio de propriedade coletiva. ${ }^{27}$ Para outros os sistemas seriam comunidade de aldeia, comunidade de família e propriedade individual. ${ }^{28}$

Segundo o sistema de propriedade coletiva, a primeira forma de propriedade foi a de apropriação comunista do solo por um grupo social. A terra cultivável, as pastagens e as florestas são exploradas em comum pelos indivíduos do grupo social, ${ }^{29}$ caracterizando o instituto que nos foi legado pelos Romanos como compáscuo.

Valcir Gassen sustenta que a propriedade coletiva das comunidades gentílicas foi a forma de propriedade que predominou nas antigas civilizações, como no Egito, na Síria e Mesopotâmia, onde tais comunidades estavam organizadas basicamente em grupos

${ }^{25}$ MONTEIRO, Washington de B., Curso de Direito Civil, 37. ed, São Paulo: Saraiva, 2003, vol.3, p. 80.

${ }^{26}$ LOPES, M M. de Serpa. Curso de Direito Civil. Direito das Coisas: Princípios Gerais, Posse, Dominio e Propriedade Imóvel. 2. ed., vol. VI, São Paulo/Rio de Janeiro: Livraria Freitas Bastos, 1962, p. 232.

27 SOUZA, Marnoco e. História das Instituições do Direito Romano, Penínsular e Portugues. Coimbra: Imprensa de Universidade, 1904, p. 319. Observa, contudo, Ralpho Monteiro Filho, que difícil é descrever com precisão qual foi a forma originária da propriedade, podendo ser dividida as opiniões sobre o assunto em duas correntes: "(i)a dos socialistas, preocupados em demonstrar a existência inicial de um comunismo geral das terras; e (ii) a dos economistas clássicos, decididos pela configuração primitiva da uma propriedade individual, de caráter absoluto e uniforme." FILHO, Ralpho Waldo de Barros Monteiro. Função social da propriedade: conteúdo e diretrizes para sua compreensão. Revista Forense. Vol. 397 p. 283.

${ }^{28} \mathrm{Cf}$, assinala Cunha Gonçalves, ainda que discorde desta distinção. GONÇALVES, Luiz da Cunha. Da propriedade e da posse. Edições Ática, 1952, p. 11.

29 Ibidem, p. 319. 
familiares, clãs e tribos, tendo a propriedade coletiva sua base no entendimento de que a comunidade predominava sobre o individuo. O que deve ser levado em conta é a comunidade, sendo assim a terra pertence ao grupo todo, tanto aos vivos quanto aos mortos, visto que eles acreditavam que os mortos permaneciam de certa forma ligados às condições terrenas. $^{30}$

Fustel de Coulanges assenta sua proposição na religião. Segundo ele quando os homens viviam em tribos familiares, o culto aos antepassados criava uma religião essencialmente doméstica. "A idéia de propriedade privada estava na própria religião. Cada família tinha o seu lar e os seus antepassados. Esses deuses só pela família podiam ser adorados, só à família protegiam; eram propriedade sua. Encontraram os antigos misteriosa relação entre estes deuses e o solo."31

De acordo com o sistema de propriedade individual, a propriedade na sua origem era semelhante a que conhecemos hoje, considerando falsa a crença dos autores de que teria se originado de outra forma. Mesmo quando a propriedade pertence à família, ela era mais individual do que comum, pois era atribuída a um membro da família, geralmente o pai. $^{32}$

Conforme Marnoco Souza tanto a propriedade coletiva como a individual são antigas, mas, na origem, teve maior extensão a propriedade coletiva, encontrando-se a propriedade individual, limitada a algumas coisas móveis de uso exclusivamente pessoal. Este sistema foi se fracionando pouco a pouco, adquirindo, face ao desenvolvimento da humanidade, cada vez maior significado, a propriedade individual. ${ }^{33}$

Cunha Gonçalves analisando a evolução do direito de propriedade, assinala que o exame do tema é causa de muitas confusões e de disparates doutrinários, que invadiram o campo da ciência jurídica, através de um grande número de intelectuais, sob o impulso da febre socialista, deturpando a ciência econômica, a sociologia, a filosofia e até a história, pretendendo adequá-las às suas idéias e paixões, no fundo das quais, sob o transparente véu

30 GASSEN, Valcir. A Natureza Histórica da Instituição do Direito de Propriedade. In Fundamentos de História do Direito, Org. Antonio Carlos Wolkmer, 2. ed, Belo Horizonte: Del Rey, p. 155-156.

${ }^{31}$ COULANGES, Fustel. A cidade antiga: estudos sobre o culto, o direito, as instituições da Grécia e de Roma. Trad. Fernando de Aguiar, 9. ed. Lisboa: Livraria Clássica Editora, 1957, p. 84-85.

32SOUZA, Marnoco e. História, ob. cit. p. 320.

33lbidem, p. 320-321.

Revista de Direito da Cidade, vol.03, nº2. ISSN 2317-7721 p.275-328 284 
da justiça, se descobre a inveja e a ambição, propulsoras de revoluções sanguinárias na Rússia e na Espanha. ${ }^{34}$

Para o mestre português, a afirmação de que a propriedade teria passado por três fases históricas sucessivas (de comunidade de aldeia, comunidade de família e propriedade individual), não tem respaldo documental, não passando de engenhosas fantasias e falsas histórias e, para rechaçar a idéia de propriedade coletiva ${ }^{35}$ termina por afirmar:

\begin{abstract}
“Antes de praticada a agricultura, porém, a propriedade era antiqüíssima, radicada e imprescindível instituição humana, porque ela é instintiva, repetimos, até nas crianças e nos animais. Cada homem não podia deixar de ter a plena propriedade dos seus alimentos, dos seus vestuários, das suas armas e utensílios, da sua casa, cabana ou caverna, que ninguém impunemente lhe disputaria. Esta propriedade é uma condição do próprio direito de vida, como atrás demonstramos (V. o vol. III, $n^{\circ}$ 289). E de tal sorte esta propriedade era individual, que, após a morte do proprietário, as coisas do seu uso, inclusive o seu cavalo, eram com êle enterrados; em alguns países, sôbre a cova do morto, eram sacrificados a sua mulher e os seus escravos. Ao passo que nenhuma prova existe do primitivo comunismo negativo ou positivo”. 36
\end{abstract}

Por certo que, quanto mais retrocedermos a pesquisa, a idéia de propriedade coletiva se afasta. É possível dar razão ao mestre português, ao imaginarmos que numa época em que havia na Terra, abundância de solo e de alimentos, era desnecessário pensar em propriedade, salvo dos bens de uso exclusivo (alimentos, vestimentas, ferramentas, armas etc.). Era o homem de regra nômade, e somente quando se dedicou a agricultura, atividade que requer sua fixação no solo é que passou a ter noção desta apropriação.

Basta pensarmos no Brasil na época do descobrimento (que não faz tanto tempo assim, considerando a idade das nações do velho mundo), que segundo a história, seria habitada apenas pelos Índios, não tinham sequer noção de propriedade individual ou coletiva como registram os livros, quando muito se admitindo a propriedade individual de suas cabanas ou cubatas, desmontáveis, exercendo uma esfera de ação nos territórios destinados a caça, pertencente a cada uma das tribos, não se podendo, em rigor, considerar como propriedade coletiva. ${ }^{37}$

34 GONÇALVES, Luiz da Cunha. Tratado de Direito Civil em Comentário ao Código Civil Portugues.

2. edição. vol. XI. Tomo I, anotado por Jayme Landim Max Limonad. S.P., Brasil: p. 175.

35 Ibidem, p. 176-177.

36 Ibidem, p. 178.

37 Ibidem, p. 179. 
Contudo, Cogliolo afirma categoricamente, que a ciência moderna, "com muitas investigações, principalmente comparando povos e tempos diversos, fixou um fato sobre o qual nenhuma dúvida é mais possível - que a primeira forma de propriedade foi a comum e que, portanto nem sempre foi conhecida a propriedade individual". ${ }^{38}$

John Gilissen salienta que a colocação do tema em modelos de propriedade decorre de uma tendência de historiadores, pensadores políticos ou por economistas, mas que a realidade é bem diferente, eis que se encontra quase sempre os quatro tipos de modelos simultaneamente, quando muito, há um tipo que predomina, sem, contudo, excluir os outros. $^{39}$

Daí porque se mostra razoável a observação feita por Eugeny Pasukanis, no sentido de que a evolução histórica da propriedade, enquanto instituição jurídica, compreendendo todos os diversos modos de aquisição e proteção, as modificações relativas aos diversos objetos, não se consumou de maneira tão ordenada e coerente, passando pelas vicissitudes da história, até chegar à idéia que se tem na atualidade. ${ }^{40}$

\section{3 - Fundamentos do Direito de Propriedade}

Varia a doutrina em apontar as teorias que se preocuparam com o exame dos fundamentos (justificação) do direito de propriedade. Cunha Gonçalves afirma que o tema tem sido objeto de larga controvérsia, controvérsia esta que se acentuou desde a propaganda das doutrinas de Marx, sendo uma questão econômica e jurídica. ${ }^{41}$ Como principais teorias, pode-se indicar: a da ocupação; a da convenção; a da lei; a do direito natural; a do trabalho; da personalidade. Vejamos em resumo cada uma delas.

\footnotetext{
38 COGLIOLO, Pietro. Philosofia de Direito Privado. Trad. de Eduardo Espínola. Bahia: Empresa Ed., 1898. p. 172.

39 GILISSEN J.. Introdução.. ob. cit., p. 636.

40 PASUKANIS, Eugeny B.. A Teoria Geral do Direito e o Marxismo. Renovar Ed., 1989, p. 86.

41 GONÇALVES, Luiz da Cunha. Da propriedade e da posse, ob. cit., p. 20.
} 


\section{1 - Teoria da ocupação}

Fundamenta-se na primitiva ocupação da coisa pelo homem quando ainda se encontrava a mesma sem dono, isto é, era "res nullius". Não existindo domínio de ninguém sobre o bem, tornou-se proprietário dele quem o ocupou e se apossou, submetendo-a ao seu poder, ocorrendo posteriormente sucessivas transmissões que só alterariam a titularidade. ${ }^{42}$

Kant, numa posição intermediária entre a propriedade como direito natural e como direito positivo, sustenta que a aquisição da propriedade no estado de natureza é provisória e, somente após o Estado, ela se torna definitiva, afirmando ainda:

\footnotetext{
"A aquisição de um objeto que se encontra fora do arbítrio, pôr meio de um ato individual da vontade, é a ocupação. A aquisição originária, portanto, deste objeto, é conseqüentemente também de um determinado solo só pode acontecer pôr meio da ocupação (occupatio)." 43
}

Apesar das críticas, em especial por sujeitar a aquisição a um ato de vontade do primeiro ocupante e pela circunstancia da ocupação como ato de aquisição só ser possível onde a lei permita, seguindo um raciocínio puramente lógico-racional, como já se mencionou acima, não parece absurdo crer que os bens sem dono, ou porque o homem não tinha a noção de propriedade e em razão da abundância deles num momento primitivo, que a tomada da posse, que em linha de principio é o primeiro ato de ocupação, tenha gerado a propriedade das coisas.

Não se trata de dar ao fenômeno da ocupação a noção do direito positivo, pois assim agindo estaríamos atraindo a existência da propriedade para o momento de nascimento do estado, o que, aliás, é parte também de uma outra teoria. A ocupação, como ato de assenhoreamento, aliado à defesa do bem que lhe sirva de objeto, parece ter sido de fato um primitivo ato de aquisição.

\section{2 - Teoria da convenção}

\footnotetext{
42 Cf. RIZZARDO, Arnaldo. Direito das Coisas. 2. ed. Rio de Janeiro: Ed. Forense, 2006, p. 180.

${ }^{43}$ Cf. NORBERTO BOBBIO. Direito e Estado ..., ob. citada, p. 105.
} 
Fundamenta-se na existência de uma convenção tácita primitiva. Segundo Pufendurff, citado por Marnoco Souza, os homens "formaram primitivamente uma convenção pela qual se comprometeram a respeitar o direito que cada um deles adquirisse sobre as coisas, ocupando-as, a fim de poderem gozar tranquiilamente os frutos de seu trabalho". 44

É perfeitamente possível imaginar este tipo de pacto implícito, tal qual o contrato social, entre membros de certa tribo, comunidade, povo, não importa a identificação que se dê, do mesmo modo como é admissível que tais grupos tenham um conjunto mínimo de normas de organização social que respeitam para a subsistência do próprio grupo.

O homem isolado é um mito. Há muito proclamara Aristóteles: “...o homem é um animal político, destinado a viver em sociedade"45 e a vida em sociedade pressupõe o respeito a um mínimo de regras e onde há regras há consequiências para sua violação.

A referencia ao respeito que cada um tem ou deveria ter sobre o que está na posse, sob domínio ou propriedade de outrem, não importa o nome que se dê ao fenômeno, só se afasta pelo espírito de cobiça, inspirador de conquistas no passado e no presente, muito mais do que o desejo de expansão territorial ou de domínio.

Segundo Hobbes há uma lei natural que estabelece que um homem concorde, quando os outros também o façam, e na medida "em que tal considere necessário para a paz e para a defesa de si mesmo, em renunciar a seu direito a todas as coisas, contentando-se em relação aos outros homens, com a mesma liberdade que aos outros homens permite em relação a si mesmo." Quando cada homem detiver seu direito de fazer tudo quanto queira "todos os homens se encontrarão numa condição de guerra."46

\section{3 - Teoria do direito natural}

Para esta teoria a propriedade deriva da própria natureza, tendo em vista ser ela uma condição necessária para existência e desenvolvimento do homem. Não há dúvida,

\footnotetext{
44 SOUZA, Marnoco e. História .., ob. cit., p. 314-315.

45 ARISTÓTELES. A Política. Trad. Nestor Silveira Chaves. 6. ed. São Paulo: Atena Editora, 1960, p. 14.

${ }^{46}$ MALMeSBURY, Thomas Hobbes. Leviatã. Trad. João Paulo Monteiro e Maria B. Nizza da Silva. São Paulo: Editor Victor Civita, p. 79.
} 
haja vista que este ponto é intuitivo e lógico, que o homem sobrevive dos bens terrenos. $\mathrm{O}$ solo e que o ele produz e para tanto não necessitaria de qualquer aprendizado, pois como um animal, ainda que racional, o instinto o levaria à pratica dos atos de sobrevivência.

Segundo Cogliolo o problema do fundamento do direito de propriedade foi longamente debatido pelos teóricos do direito natural. Estas teorias podem ser divididas em dois grandes grupos: "aquelas que afirmam que a propriedade é um direito natural, ou seja, um direito que nasce no estado de natureza, antes e independentemente do surgimento do Estado, e aquelas que negam o direito de propriedade como direito natural e, portanto, sustentam que o direito de propriedade nasce somente como conseqüência da constituição do estado civil", 47

Não se desconhece o debate entre positivistas e jusnaturalistas não só quanto a existência destes dois sistemas normativos, mas também quanto a oposição entres eles, quanto a supremacia de um sobre o outro e até mesmo quanto a inter-relação entre eles.

Garcia Maynez analisando o tema em referencia, noticia a existência de diversas correntes de pensamento a respeito do direito natural, dando origem ao jusnaturalismo teológico, originário da divindade; jusnaturalismo sociológico, originário da natureza social ou sociabilidade natural do homem e jusnaturalismo racionalista, originário da razão humana. ${ }^{48}$ Por sua vez Larenz salienta que em sua acepção tradicional, a expressão direito natural tem significado sempre de um direito imutável, pelo menos em suas linhas fundamentais, válido por igual para todos os povos, enquanto está fundado na essência do homem. ${ }^{49}$ No entanto, segundo Leoni no século XX há como um pacto social onde o direito

47 COGLIOLO, Pietro. Philosofia de Direito Privado. Trad. de Eduardo Espínola. Bahia: Empresa Ed., 1898, p. 170.

48 MÁYNES, Eduardo García. Introduccion al Estúdio del Derecho. 4. ed. México: Editorial Porrua S.A., 1951, p. 40-43.

49 LARENZ, Karl. La Filosofia Contemporânea del Derecho y del Estado. Trad. E. Galán Gutiérrez y A. Truyol Serra. Madri: Ed. Revista de Derecho Privado, 1942, p. 212. Talvez uma das maiores dificuldades em admitir a existência de um direito natural seja justamente a visão tradicional de que ele é imutável, eterno e universal. A respeito deste ponto e contra este entendimento, Maynez acima citado, assinala: "La doctrina contraria - única verdadera, em nuestra opinión - vê em el derecho natural la regulación justa de cualquier situación concreta, presente o venidera, y admite, por ende, la variedade de contenidos del mismo derecho, em relación com lãs condiciones y exigências, siempre nuevas, de cada situación especial; sin que lo dicho implique la negación de uma seria de princípios supremos, universales y eternos, que valen por si mismos y deben servir de inspiración o pauta para 
natural faz concessões ao direito positivo e este àquele, a fim de que ambos possam conviver harmonicamente. ${ }^{50}$

Para os jusnaturalistas segundo registra Bessone a propriedade constitui um direito natural do homem. Para alguns um direito natural próprio ou direito por ser da natureza do homem de tornar-se proprietário, ou senhor de bens ou coisas. Para outros, o é indiretamente, uma vez que não sendo a propriedade indispensável à natureza da pessoa humana, é, no entanto, uma condição de seu bem estar. Uma condição da realização da vida humana, da qual o homem não poderia prescindir, daí porque seria um direito natural indireto. ${ }^{51}$ Eduardo Espínola afirma que há um pronunciada tendência atual para considerar a propriedade como um direito natural, no sentido de ser inerente à natureza humana e indispensável à convivência social. ${ }^{52}$

\section{4 - Teoria do trabalho ou da especificação.}

Segundo esta teoria a origem da propriedade deriva do trabalho. O homem cultivando a terra e utilizando as coisas externas à satisfação de suas necessidades, imprime aos objetos o cunho de sua personalidade, fazendo-os sair da comunidade primitiva, aberta

la solución de los casos singulares y la formulación de las normas concretas aplicables a estes. Son aquéllos los princípios supremos del derecho natural. (ob. cit. p. 49). A defesa da visão positivista pode-se colher em Gropalli que escreve: "Negamos sempre que possam existir verdadeiros e autênticos direitos natos do homem, anteriores ao Estado, porque não podem existir direitos que não sejam reconhecidos e protegidos por ele." Este mesmo autor, mais a frente considera que a pessoa humana tem exigências naturais e invioláveis, como a de viver, de se mover, de gozar o produto da sua própria actividade, de ter e exprimir seu pensamento, de se respeitada na sua integridade física e moral, de ter uma família, etc., exigências que se alargam com a evolução da sociedade e que se transformam em verdadeiros direitos subjectivos quando o ordenamento jurídico as eleva, criando as respectivas acções, à categoria de direito de agir contra aqueles que se dispuserem a violá-las." GROPALLI, Alessandro. Introdução ao Estudo do Direito. Trad. Manuel de Alarcão. Coimbra: Coimbra Editora, 1974, p. 81-82.

50 OLIVEIRA, J.M. Leoni Lopes de Oliveira. Introdução ao Direito. 2. ed. Rio de Janeiro: Lúmen Júris, 2006, p. 39.

51 BESSONE, Darcy. Direitos Reais. Ed. Saraiva, 1988, p. 24-25.

52 ESPÍNOLA, Eduardo. Posse-Propriedade, Compropriedade ou Condomínio, Direitos Autorais. Rio de Janeiro: Conquista, 1956, p. 130. 
aos esforços de todos. Em razão desta transformação o homem torna-se criador dos objetos e assim, adquire o direito de considerá-lo sua propriedade. Segundo Locke o direito de propriedade decorre de um fato unilateral e verdadeiramente natural, assim como é o trabalho, sendo por meio deste que o homem usufrui da terra, cultiva-a, deixa-a fértil e frutífera. É justo, portanto que quem trabalha uma determinada porção de terra comum adquira o direito de usufruir dela com todos os benefícios relacionados, excluindo os outros do usufruto, o que de fato constitui a propriedade. ${ }^{53}$ Também neste sentido Rosseau, assinalando:

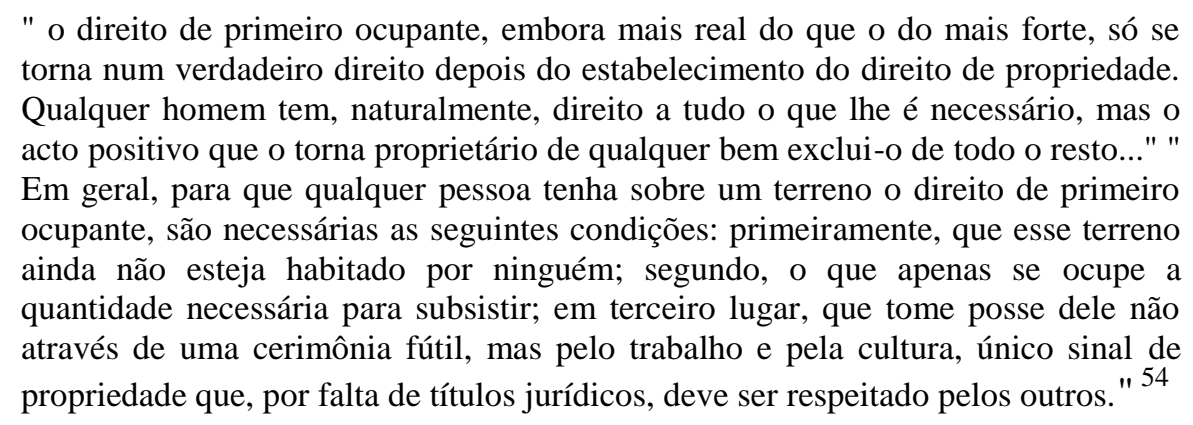

Esta teoria foi revisitada por Fachin ao analisar o principio da função social da propriedade, ao sustentar que tal principio não chega a afirmar que o trabalho se constitui no único modo de ter a propriedade mas " que somente o trabalho do homem sobre a terra é que legitima a sua propriedade." 55 Em verdade por força da constituição federal não se pode admitir propriedade desfuncionalizada, sem utilização ou subutilizada e tal utilização, na propriedade rural se dará pelo trabalho do homem no campo e por sua moradia e nas cidades, pela gama de atividades que o bem objeto do direito possibilitar ao titular.

${ }^{53}$ Cf. se lê em Norberto Bobbio. Direito e Estado..., ob. citada, p. 105.

54 ROUSSEAU, Jean-J. O Contrato Social .Trad. de Leonaldo M.P. Brum, Publicações EuropaAmérica, p. 27. O mesmo Rosseau em 1755, em Discurso sobre a origem e os fundamentos da desigualdade entre os homens, escrevera: "O primeiro que, tendo cercado um terreno, se lembrou de dizer: Isto é meu, e encontrou pessoas bastantes simples para o acreditar, foi o verdadeiro fundador da sociedade civil. Quantos crimes, guerras, assassínios, misérias e horrores não teria poupado ao gênero humano aquele que, arrancando as estacas ou tapando os buracos tivessem gritado aos seus semelhantes: Livrai-vos de escutar esse impostor; estareis perdidos si esquecerdes que os frutos são de todos, e a terra de ninguém. ROUSSEAU, Jean-Jacques.Discurso sobre a Origem da Desigualdade. Trad. de Maria Lacerda de Moura. Rio de Janeiro: Athena Editora, s/d, p. 124, grifado no original.

55 FACHIN, Luiz E. A Função Social da Posse e a Propriedade Contemporânea. Porto Alegre: Sergio A Fabris Editor, 1988, p. 18. 


\subsection{Teoria individualista ou da personalidade}

Segundo Radbruch a uma concepção estática da propriedade privada contrapõe-se uma concepção dinâmica, a qual exige uma constante integração entre o homem e a coisa possuída, de modo que continuamente se encha de uma atividade que a fecunde, que seja continuamente utilizada, como se fosse uma obra que estivesse sendo produzida de modo continuo, permanente, através da ocupação e especificação (trabalho). ${ }^{56}$

Para esta teoria, segundo o mesmo autor, não é a propriedade o mesmo que um domínio do homem sobre as coisas, mas uma certa relação entre o homem e as coisas. Não são só os homens a tirar utilidade das coisas; as coisas tem algo a exigir dos homens; exigem deles que as utilizem, que as gozem, as cultivem e as poupem, segundo o valor que elas têm. O ponto central seria uma espécie que afeição que teria o homem pelas suas coisas, o que serviria para justificar a propriedade de objetos pessoais como vestuário, à habitação, os livros, etc., mas não justificaria a propriedade em relação às fábricas, bancos e grandes latifúndios. ${ }^{57}$

No entanto essa visão individualista da propriedade inspira nossos autores quando definem o direito de propriedade, a começar pelos clássicos até àqueles que podemos considerar como modernos. Para Lafayette o domínio "é o direito que vincula e legalmente submete ao poder absoluto de nossa vontade a cousa corpórea, na substancia, acidentes e acessórios". ${ }^{58}$ Tito Fulgêncio afirma que propriedade "é o direito que tem uma pessoa de tirar diretamente da coisa toda sua utilidade jurídica." ${ }^{59}$ Lacerda Almeida diz que propriedade é "o direito real que vincula à nossa personalidade uma coisa corpórea sob todas as suas relações." ${ }^{60}$ Orlando Gomes no seu manual dizia: “é o direito complexo, absoluto, perpétuo e

56 RADBRUCH, Gustav. Filosofia do Direito. Trad. L. Cabral de Moncada. 6. ed. Coimbra: Armênio Amado Editor, Sucessor, 1979, p. 272.

57 Idem, p. 273-274. Na verdade o autor faz um amplíssimo exame desta teoria, desenvolvendo o exame a partir da p. 272 até a p. 278, quando passa a analisar as teorias sociais da propriedade.

58 PEREIRA, Lafayette R. Direito das Coisas. Vol I.Brasília: Senado Federal, 2004, p. 98.

59 FULGÊNGIO, Tito. Direito de vizinhança. Rio de Janeiro: Forense, 1959, p. 7.

60 ALMEIDA, Francisco de P. Lacerda de. Direito das cousas. Rio de janeiro: Ribeiro dos Santos, 1908, p. 72. 
exclusivo, pelo qual uma coisa fica submetida à vontade de uma pessoa, com as limitações da lei.",61

Essas noções estão intimamente ligadas ao reconhecimento da propriedade como um direito subjetivo da pessoa, traduzindo um conceito clássico do direito de propriedade, onde o instituto é examinado apenas com enfoque no titular e nos deveres dos não proprietários em respeitá-lo.

\title{
3.6 - Teoria da criação da lei ou positivista
}

Para esta teoria a propriedade foi criada pelo Estado, não tendo a propriedade caráter jurídico sem a lei ou antes da lei.Neste sentido é o pensamento de Hobbes:

\begin{abstract}
“... antes da constituição de um estado todas as coisas estão em situação comunitária, e não há nada que alguém possa dizer ser seu sem que um outro possa dizer, com o mesmo direito, a mesma coisa (quando tudo é comum, nada é propriedade dos indivíduos singulares), deriva de que o conceito de propriedade surgiu pôr meio da constituição do Estado; e se afirma que é propriedade de alguém aquilo que ele pode deter para sí, segundo as leis e em virtude da autoridade do Estado, ou seja, em virtude da vontade de quem detém a soberania". 62
\end{abstract}

Para esta teoria a propriedade existe porque a lei quer e existirá enquanto a lei quiser, portanto seria a propriedade concessão do direito positivo.

Por certo que o direito positivo é fruto da organização social e política do homem e tal organização é o Estado. Edward Burns descreve o Estado como uma sociedade organizada que ocupa um território definido e possui um governo efetivo, independente de controle externo. A essência do Estado é a soberania, ou o poder de fazer e executar leis, preservando a ordem social pela punição daqueles que infringem essas leis. ${ }^{63} \mathrm{O}$ Estado é uma situação de convivência humana em sua forma mais elevada, dentro das condições de cada época e de cada pais segundo Georg Fischbach. ${ }^{64}$

61 GOMES, Orlando. Direitos reais. 19. ed. Rio de Janeiro: Ed. Forense, 2004, p. 109.

62 HOBBES, Principi di Diritto Naturale, p. 63, apud Norberto Bobbio. Direito e Estado no Pensamento de Emanuel Kant. $2^{\mathrm{a}}$ edição. Editora Universidade de Brasília, 1992, p. 103.

63 BURNS, Edward Mcnall. História da Civilização Ocidental. $1^{\circ}$ vol. Trad. Alexandre Costa. Rio de Janeiro: Ed. Globo S/A, 1980, p. 34.

64 FISCHBACH, Oskar Georg. Teoria General del Estado. Trad. Rafael L. Tapia. 4. ed. Barcelona: Editorial Labor S/A., 1949, p. 7. 
Não há dúvida de que o homem politicamente organizado tem melhores possibilidades de atender às suas necessidades como individuo e às necessidades familiares, núcleo onde certamente estará inserido e não pode haver dúvida também, que a existência de um ente como o Estado possibilita o atingimento de seus objetivos como pessoa, proporciona maior segurança, solidariza os benefícios e ameniza os problemas de seu desenvolvimento.

O direito de propriedade como o conhecemos, não só de sua percepção mas com base nas lições de nossos antepassados, que já conheciam o Estado como forma política de organização social, é relativamente recente. É um conceito jurídico e não fático, pois só o jurídico permite a compreensão da extensão encontrada no direito de propriedade. Também só o jurídico permite o raciocínio abstrato que se confere à propriedade.

No entanto, quando identificamos os fenômenos sociais de nossos antepassados para melhor compreender as instituições do presente e aperfeiçoá-las para as futuras gerações, vamos identificar um ato de apossamento que vai resultar no mesmo fenômeno que a inteligência humana resolveu chamar de propriedade, por isso, podemos afirmar que a propriedade, seja ela tribal, familiar, individual ou pública é anterior à sua "juridicização" 65 . Preferível é reconhecer o acerto de Rizzardo na afirmação: "Em verdade sempre existiu a propriedade, mesmo antes da formulação de sua disciplina legal. O que se admite à lei é regular o exercício da propriedade, ou a sua manifestação.",66

A este respeito Villey escrevera: ... este poder "de gozar y de disponer" que se considera em principio absoluto, no podría em buena lógica ser uma creación de la Ley: la Ley solamente lo sanciona dentro de ciertos limites." ${ }^{, 67}$

\section{7 - Síntese da questão}

Por certo hoje é possível reconhecer que as teorias que procuram fundamentar ou justificar a propriedade privada embora sejam colocadas ou examinadas como reciprocamente contraditórias e excludentes, em verdade, pode-se afirmar, ao contrário, que elas se entrelaçam e refletem uma evolução histórica no exame da questão. Alguns autores

\footnotetext{
$65 \mathrm{KICH}$, Bruno C. A Propriedade na Ordem Jurídica, Econômica e Ideológica...ob. cit. p. 13. ${ }^{66}$ RIZZARDO, Arnaldo. Direito das Coisas... ob. cit. p. 180.

67 VILLEY, Michel. Estúdios em torno da la nocion de Derecho Subjetivo. Ediciones Universitárias de Valparaiso. Universidad Católica de Valparaiso, 1976, p. 154.
} 
consideram que houve uma seqüência: ocupação, trabalho e por último o reconhecimento da lei. $^{68}$

Neste ponto, Cogliolo após referir-se as diversas teorias diz estranhar que se queira encontrar uma causa simples e única para uma instituição tão grande e varia, eis que a propriedade é um fato social, que existe em todos os tempos e todos os povos civis, surgindo e se desenvolvendo com a civilização, e sobre ela se funda, e remata:

\begin{abstract}
“As causas que geraram a propriedade individual são as mesmas que geraram o progresso, isto é multiplas e complexas e não uma única e simples; a natureza da agricultura intensiva, differente da pastoricia errante; as exigencias do trabalho humano; a tendência do homem a apoderar-se das coisas com exclusão dos outros; a constituição do consorcio social; o desenvolvimento parallelo da familia, do indivíduo e do Estado; estes e outros factores da civilização foram as causas da propriedade individual", 69
\end{abstract}

A partir do momento do surgimento do homem, seja fruto da teoria criacionista seja fruto da teoria evolucionista, é possível reconhecer a apropriação, como uma relação de pertencialidade dos elementos existentes na natureza para sua alimentação, para sua proteção contra intempéries e para sua segurança. Esta relação de pertencialidade tinha que ser respeitada e protegida de algum modo. O homem precisava administrá-la de algum modo, defendendo-a de seus inimigos ou predadores. Pela força, com a vida ou com armas ou ainda através de uma instituição como o estado, criada pelo homem para solidarizar suas questões e problemas individuais, sob pena de conflito, guerra ou litígio.

Esta situação de apropriação é um modo de propriedade e tal reconhecimento é indiscutível em nossos tempos, mas não é possível identificar em que momento histórico o homem construiu a noção de que este ato de apropriação corresponderia a tão importante instituto da era moderna. Aliás, Villey demonstra a insegurança que existe em afirmar que nesta ou naquela nação antepassada uma determinada relação ou ato, corresponda aos conceitos modernos que aplicamos. Em especial conceitos como direito subjetivo e direito de propriedade. $^{70}$

Num momento histórico que se pode dizer de inauguração do constitucionalismo moderno, isto é, das declarações de direitos do homem já referidas, a

\footnotetext{
68 PAPANO, Jose R., KIPER, Cláudio M., DILLON, Gregório A., CAUSSE, Jorge R. Derechos Reales. Tomo I. Buenos Aires: Ediciones Depalma, 1993, p.159.

69 COGLIOLO, Pietro. Philosofia de Direito Privado..., ob. citada, p.177.

70 Idem, p.127-148.
} 
propriedade foi considerada um direito natural e inviolável. Ora, qual seria a natureza jurídica da posse dos índios das terras brasileiras ${ }^{71}$ para tomar como hipótese a propriedade entre nós? Que direito ou que fundamento teriam os portugueses de esbulhar a posse dos nativos que aqui viviam e apropriar-se de todas as terras? ${ }^{72}$

Aliás, ainda hoje esta questão se discute, considerando que existem no Brasil nações nativas que utilizam das terras desde seus antepassados, defendendo-as dos invasores da cidade e que reclamam constante proteção, gerando por vezes conflitos sangrentos como noticia a imprensa. Não raro a situação bate as portas dos Tribunais não só com relação à invasão das terras indígenas, mas também com relação à sua demarcação e limites. Veja-se por ex., o julgados do STF a respeito: RMS 23642/DF, Min. Sepúlveda Pertence, julgado em 05.04.2005, $1^{\text {a }}$ Turma; Pet-AgR 3755/RR, Rel. Min. Carlos Britto, julgado em 21.02.2008, Tribunal Pleno; MS-21896/PB Rel. Min. Carlos Velloso, julgado em 04.06.2007, Tribunal Pleno; ADI 1512/RR, Rel. Min. Mauricio Corrêa, julgado em 07.11.1996, Tribunal Pleno.

Recentemente o pleno do STF julgou Mandado de Segurança que discutia a delimitação da Reserva Raposa Serra do Sol, em que se antevia a possibilidade de conflito de

71 Pedro Calmon traz o relato do escrivão da esquadra de Cabral, informa que no dia 27/05/1500, entraram numa aldeia, onde havia nove ou dez casas grandes com trinta ou quarenta pessoas em cada uma, ou seja, entre trezentos ou quatrocentos índios (CALMON, Pedro. História do Brasil. RJ: José Olímpio,vol.VI, 1959, p. 60). Cf. registro de Sergio B de Holanda, da tribo dos Tupis se tem maior registro, apesar da existência aqui de vários grupos etnicamente distintos ${ }^{71}$, devido ao fato de terem sido os que primeiro tiveram contato com os portugueses, pois habitavam o litoral dos atuais estados do Rio de Janeiro, Bahia, Maranhão, Pará, tendo sido também a principal fonte de resistência organizada aos desígnios dos colonizadores, mas também ponto de apoio para o contato com outras populações nativas (HOLANDA, Sergio Buarque. A Época Colonial. São Paulo: Difusão Européia do Livro, Tomol, vol. 2, 1960, p. 72-80) Cf. João Ribeiro, portugueses e índios praticavam-se mutuamente crueldades, porque não se entendiam e nem se podiam entender pelos diferentes graus de civilização. O índio tinha o sentimento da propriedade coletiva (da tribo), mas não o tinha da propriedade privada. (RIBEIRO, João. Historia do Brasil. 16. ed. Rio de Janeiro: Livraria São José, 1957, p. 49)

${ }^{72}$ Os indígenas exerciam sobre a terra a posse mansa e pacífica (ressalvada a disputa entre as tribos), fundamental para sua subsistência, e nela praticavam a horticultura, a coleta, a caça e a pesca. Talvez numa palavra mais apropriada, seu domínio sobre ela se dava num sistema de propriedade coletiva, que, aliado à liberdade diante da necessidade de defesa, os transformou em inimigos terríveis, lutando, dentro de suas possibilidades, ardorosamente. A "terra constituía o seu maior bem e o grau de domesticação do meio natural circundante, assegurado pelos artefatos e técnicas culturais de que dispunham, fazia com que sua sobrevivência dependesse de modo intenso e direto" da dominação ocasional ou permanente do espaço que ocupassem. (RIBEIRO, João. História... ob. cit., p. 46, p. 72-73). 
grandes proporções entre indígenas e fazendeiros da região, tendo o Tribunal, a despeito das pressões políticas e econômicas reconhecido o direito dos indígenas às terras, merecendo transcrição, em razão da conexão o estudo desenvolvido neste ensaio, a ementa do julgamento:

"MANDADO DE SEGURANÇA. HOMOLOGAÇÃO DO PROCEDIMENTO ADMINISTRATIVO DE DEMERCAÇÃO DAS TERRAS INDÍGENAS RAPOSA SERRA DO SOL. IMPRESTABILIDADE DO LAUDO ANTROPOLÓGICO. TERRAS TRADICIONALMENTE OCUPADAS POR ÍNDIOS. DIREITO ADQUIRIDO À POSSE E AO DOMÍNIO DAS TERRAS OCUPADAS IMEMORIALMENTE PELOS IMPETRANTES. COMPETÊNCIA PARA A HOMOLOGAÇÃO. GARANTIA DO DEVIDO PROCESSO LEGAL ADMINISTRATIVO. BOA-FÉ ADMINISTRATIVA. ACESSO À JUSTIÇA. INADEQUAÇÃO DA VIA PROCESSUALMENTE ESTREITA DO MANDADO DE SEGURANÇA. AUSÊNCIA DE DIREITO LÍQUIDO E CERTO. A apreciação de questões como o tamanho das fazendas dos impetrantes, a data do ingresso deles nas terras em causa, a ocupação pelos índios e o laudo antropológico (realizado no bojo do processo administrativo de demarcação), tudo isso é próprio das vias ordinárias e de seus amplos espaços probatórios. Mandado de segurança não conhecido, no ponto. Cabe à União demarcar as terras tradicionalmente ocupadas pelos índios (caput do artigo 231 da Constituição Federal). Donde competir ao Presidente da República homologar tal demarcação administrativa. A manifestação do Conselho de Defesa Nacional não é requisito de validade da demarcação de terras indígenas, mesmo daquelas situadas em região de fronteira. Não há que se falar em supressão das garantias do contraditório e da ampla defesa se aos impetrantes foi dada a oportunidade de que trata o artigo $9^{\circ}$ do Decreto 1.775/96 (MS 24.045, Rel. Min. Joaquim Barbosa). Na ausência de ordem judicial a impedir a realização ou execução de atos, a Administração Pública segue no seu dinâmico existir, baseada nas determinações constitucionais e legais. O procedimento administrativo de demarcação das terras indígenas Raposa Serra do Sol não é mais do que o proceder conforme a natureza jurídica da Administração Pública, timbrada pelo auto-impulso e pela auto-executoriedade. Mandado de Segurança parcialmente conhecido para se denegar a segurança.” (MS 25483/DF, Rel. Min. Carlos Brito, julgado em 04.06.07, Tribunal Pleno).

Por sua vez, em decisão de novembro de 2008 o Incra destinou 78,1 mil hectares de terras próximas à base militar de Alcântara, por reconhecer direito a elas, aos descendentes de Quilombolas. ${ }^{73}$ E recentemente o Min. da Defesa Nelson Jobim interferiu politicamente numa questão que perdurou por mais de 30 anos de disputa judicial entre ocupantes de áreas que pertenceriam ao Exército, cujo direito à elas teria sido reconhecido ao Exército, para manutenção da comunidade que há ocupa, incluindo os descendentes há mais de 100 anos.

No ano de 2008 uma atrativa e valorizada região praiana da cidade de Niterói, antiga capital do Estado do Rio, conhecida por Camboinhas, supervalorizada por suas mansões e condomínios, recebeu "indesejados" visitantes indígenas tupis-guaranis que se

${ }^{73}$ Cf. Reportagem de Catarina Alencastro, publicada in O Globo de 04.02.2009, p. 10. 
mudaram para o local, com fundamento no direito às terras que pertenceram aos seus antepassados e onde existe um cemitério indígena da Duna Grande de Itaipu, constituindo a aldeia Tekoá Mboy-ty e se recusam, para desagrado dos investidores e moradores da região, a sair do local. Esta atitude da tribo sem dúvida corresponde a ligação do homem com o solo, no culto aos deuses domésticos referidos acima por Fustel de Coulanges, ${ }^{74}$ prática que foi transmitida de geração em geração. A questão foi levada à Justiça Federal através de uma ação cautelar e uma ação civil pública ajuizada pela associação do bairro - Soprecam contra a Funai, feitos estes distribuídos à $3^{\mathrm{a}}$ Vara Federal de Niterói, tendo sido concedida liminar determinando que a Funai identifique e cadastre todos os indígenas e impeça a vinda de outros. $^{75}$

Algumas indagações são possíveis em tema de propriedade entre nós. A propriedade (se assim podemos identificar a relação de posse da terra) de nossos antepassados indígenas decorria do direito natural, do direito do primeiro ocupante, do trabalho e especificação sobre a terra ou de todas estas hipóteses em conjunto? E a posse das terras por nossos antepassados portugueses: um direito de ocupação decorrente da conquista pela força como sempre aconteceu na história das civilizações? ${ }^{76}$ Isto é, em cada tempo uma nação domina certa região e os povos conquistados. ${ }^{77}$ Da dádiva divina através das bulas papais? ${ }^{78}$ Da convenção decorrente dos tratados firmados na época dividindo o mundo novo em duas partes a serem conquistas pela Espanha e por Portugal ou seria mesmo um histórico

\footnotetext{
${ }^{74}$ Cf. Reportagem de Rafael Galdo, in O Globo - segmentos de bairros - Niterói, p. 4 de 08.02.2009.

75 Disponível no sitio da Justiça Federal: ação cautelar processo n 2008.5102.001616-2; ação civil pública processo $n^{\circ} 2008.5102 .003177-1$.

${ }^{76}$ Afirma Conselheiro Ribas que: "Os primeiros colonizadores do nosso pais acharam-se em presença de imensas florestas e extensíssimos campos, sem dono.Dizemos, sem dono, porque os seus míseros íncolas primitivos eram reputados incapazes de direitos.Se nem direito tinham à sua liberdade e à sua vida, como poderiam tê-lo a suas florestas e campos? Duvidou-se até alguns se pertenciam à raça humana, se eram capazes dos sacramentos da igreja; posto que viesse afinal a prevalecer a afirmativa.É certo que, de direito, esta extensíssima região, que constitui a nossa pátria, tinha um dono, o rei de Portugal. (RIBAS, Antonio Joaquim. Da Posse e das Ações Possessórias. São Paulo: Ed Miguel Melillo \& Cia, , s/d, p. 6, grifos nossos).

77 Veja-se a respeito Linhares de Lacerda, Terras do Brasil, ob. cit. e Edward Burns, Historia da Civilização. ob. citada.

${ }^{78}$ Cf. Antonio Saldanha, no caso das terras habitadas o domínio régio se fundava na força e virtude dos diplomas pontifícios de doação. (SALDANHA, António Vasconcelos. As capitanias do Brasil. Comissão Nacional para as Comemorações dos Descobrimentos Portugueses. Lisboa, 2001, p. 46)
} 
ato de grilagem dos portugueses sobre nossas terras como afirmou Miguel Baldez? ${ }^{79}$ Eram terras públicas, porque pertencentes à Coroa portuguesa, que foram gradativamente se transformando em terras privadas, em especial à partir da Lei de Terras? ${ }^{80}$

A ocupação como ato de aquisição reconhecido pelo direito positivo guarda semelhança, mas não identidade com o ato de ocupação de terras. Mas, o ato de ocupação em si e, sua continuidade gera efeitos possessórios e dominiais. Esta foi a tese, conforme registro de Santi Romano, encampada pela decisão arbitral do Rei da Itália de 28 de janeiro de 1931, com base em parecer neste sentido por ele elaborado, na disputa entre França e México a respeito da ocupação de territórios nullius da Ilha de Clipperton. ${ }^{81}$

Por outro lado, a partir da existência do Estado, não importa a época de seu nascimento nem sua conformação política, concentrando as funções de organização e controle social da comunidade, mister seria admitir que o Estado passasse a controlar e regular o direito de propriedade, seja admitindo a propriedade privada seja estabelecendo o predomínio da propriedade pública com objetivo de propriedade comunitária como a propriedade tribal de outrora.

Se a melhor distribuição da propriedade possibilita como dizem os teóricos da justiça melhor atendimento às necessidades do homem e maior possibilidade de satisfação de seu espírito, a solução encontrada pelo socialismo teórico, parece mais justa que o capitalismo prático. Daí a necessidade de mudança de foco do Estado, de uma indiferença em nome da liberdade a uma intervenção em nome da socialidade, a partir de um estado assistencialista, que não mais se limita a mediar as relações privadas e controlar as regras do jogo, mas intervém incisivamente em busca de objetivos fundamentais de justiça social. Altera-se a meta da justiça retributiva, conquista da revolução francesa, para dar lugar à

79 BALDEZ, Miguel Lanzellotti. Solo Urbano. Coleção "seminários" $n^{\circ}$ 6, 2. ed.. Rio de Janeiro: AJUPE/FASE, 1986, p. 1.

${ }^{80}$ Lima Pereira assinala que, remontando aos primórdios da formação da propriedade imóvel no Brasil, constata-se que toda a terra, no início, era domínio da nação portuguesa, "isto é, do domínio público "e que durante "o período colonial, como depois da independência, ella se foi desmembrando, de conformidade com os princípios de direito reguladores da transferência da propriedade do poder público para os particulares e destes entre si."Afirma ainda que esse desmembramento se operou por meio de concessões de sesmarias, compra e venda, doação, permuta, legitimação de posses. (PEREIRA, J.O de Lima. Da Propriedade no Brasil. Casa Duprat, 1932, p. 5, preservada a grafia original).

81 ROMANO, Santi. Fragmentos de un Diccionario Jurídico. Trad. Sentis Melendo e Marino Redín. Buenos Aires: Ediciones Jurídicas Europa-América, 1964, p. 66. 
"justiça distributiva, com o acentuado intervencionismo estatal" que no Brasil "é fartamente documentado a partir dos anos 30.,

À partir das declarações de direitos da Virginia em 1776 e da França em 1789 a propriedade privada é distribuída ou deve ser distribuída democraticamente. Passa a ter a proteção do estado moderno, Estado de Direito para logo incorporar-se as nascentes constituições, elaboradas pelo consenso dos cidadãos, cujos comandos deviam ser observados por estes, mas também pelo Estado e por seus agentes. ${ }^{83}$ Na expressão de Adolfo Posada: "la esencia jurídica del régimen constitucional hállase contenida en las Declaraciones de Derechos." 84

O direito de propriedade passa então a ter proteção constitucional, orientação que se espalha pelas diversas nações, proteção que vai gradativamente acompanhando o evolver das discussões sobre a propriedade como um direito individual e sua função econômica e social, consoante a necessidade de intervenção acima referida. Esse movimento se inicia no final do século XIX com Ihering, Gierke, Marx, Weber e Leon Duguit, ${ }^{85}$ e incorpora-se à Constituição Mexicana de 1917 e à Constituição Weimar de 1919 e vai num crescendo durante todo século XX, inspirando outras constituições como a Constituição do Brasil de 1934, da Colômbia de 1945, da Itália de 1948, da Alemanha de 1949, de Portugal de 1976, da Espanha de 1978 até chegar ao século XXI.

Passa a propriedade privada nos países de inspiração romano-germânica a ter fundamento na própria constituição, mas este fundamento está intimamente ligado à função social do direito, positivando uma propriedade funcionalizada a serviço do titular e a serviço da comunidade, mudando do status infra-constitucional para o constitucional.

No entanto, esta mudança de status implicou no reconhecimento de que a noção clássica de propriedade considerada como o direito subjetivo mais completo,

82 TEPEDINO, Gustavo. A Tutela da Propriedade Privada na Ordem Constitucional. Revista da Faculdade de Direito da UERJ, vol. 1, 1993, p. 111.

83 Cf Bruno Kich a Declaração de Direitos influenciou na França a Constituição Gerondina de 1791 e a Constituição Jacobina de 1793. In a Propriedade na Ordem Jurídica... ob. cit., p. 19.

84 POSADA, Adolfo. Estúdio preliminar. La Declaración de Los Derechos del Hombre y Del Ciudadano. Madrid: Libreria General de Victoriano Suárez, 1908, p. 35.

85 SOLON, Ari Marcelo. A função do conceito de direito subjetivo de propriedade. Dissertação de Mestrado apresentado na USP. São Paulo, 1987, p. 27 a 46. 
espinha dorsal do direito privado, o cerne do direito das coisas ${ }^{86}$ ao qual, como já se viu, eram atribuídos todos os benefícios e vantagens que o objeto do direito e a abstração do próprio direito permitia ao titular, não atendia mais aos anseios e necessidades dos novos tempos. Daí o reconhecimento de que ser proprietário implicava também num feixe de obrigações, entre os quais interesses não proprietários e interesses sociais têm certo relevo para a comunidade, implicando no reconhecimento de que o direito de propriedade é uma relação jurídica complexa. Tal reconhecimento implica em admitir como idéia nela incluída a bilateralidade que se estabelece entre os sujeitos, visando a tutela de um interesse. É, no dizer de Francisco Amaral, quando várias relações se entrelaçam, criando uma pluralidade de direitos e deveres entre às partes. ${ }^{87}$ Quando de um mesmo fato originam uma pluralidade de direitos e deveres ou sujeições conforme Manuel de Andrade $^{88}$ ou ainda quando uma serie de direitos subjetivos ou sujeições estão conexionadas ou unificadas por um qualquer aspecto, porque, por ex., promanam do mesmo fato ou visam o mesmo escopo na palavras de Mota Pinto. ${ }^{89}$ Esse complexo de direito e obrigações, na hipótese em estudo, promanam de um mesmo fato ou fenômeno que é a propriedade, ou melhor: propriedades nos seus diversos estatutos.

Há, no dizer de Rodotá uma insuficiência na técnica proprietária clássica, considerando a existência de um momento coletivo, nos quais não se pode justificar a propriedade através da lógica dominical. Em verdade trata-se de áreas em que deveria predominar uma lógica não dominical, como as demandas relativas ao meio ambiente, da saúde, do controle sobre os investimentos industriais. ${ }^{90}$

Não pode haver dúvida que este "momento coletivo" só pode ser admitido na propriedade em que a função social tenha lugar de destaque. Como salienta Tepedino não atende na atualidade a idéia de função social do passado, caracterizada "pela apropriação em si, como forma máxima de expressão e de desenvolvimento da liberdade humana", dogmática vigente na codificação oitocentista e em nosso código civil anterior. ${ }^{91}$

No entanto, ocorreu uma tendência universal a funcionalização do direito de propriedade como relata Trabucchi, na seguinte passagem:"Nella tendenza degli ultimi tempi verso forme piú sociali di concezione del mondo, i legislatori e gli organi chiamati

${ }^{86}$ RODRIGUES, Silvio. Direito Civil. Direito das Coisas. 28. ed. São Paulo: Saraiva, vol. 5, 2003, p. 76-77.

87 AMARAL, Francisco. Direito Civil. Introdução. Forense, 1991, p. 164-/165.

88 ANDRADE, Manuel A. Domingues. Teoria Geral da Relação Jurídica. Vol 1. Coimbra: Livraria Almedina, 1983, p. 4.

89 PINTO, Carlos Alberto da M. Teoria Geral do Direito Civil. $4^{a}$ reimpressão. Coimbra Editora Lda, 1980,

p. 142.

${ }^{90}$ RODOTÁ, Stefano. El Terrible derecho...ob cit., p. 41, p. 68.

91 TEPEDINO, Gustavo. A Nova Propriedade. RF, nº 306, 1989, p. 74. 
all'applicazione delle leggi sono propensi ad attenuare la rigida impronta individuale del diritto di proprietà, per togliere allo stesso quel carattere assoluto, che si collega alla concezione romana e che ha trovato piena affermazione nello spirito dominante del secolo passato". 92

Disso resulta a necessidade de revisitação do conceito de propriedade em razão desta reação social que se tornou jurídica, realçando a função social do direito, ainda que saibamos que todo direito tem uma função social já que o homem é um ser social.

\section{4 - Conceito de Propriedade}

O conceito do direito de propriedade após o reconhecimento da existência do Estado, varia conforme o sistema político que esteja inserido e também, sem dúvida de acordo com a ordem jurídica vigente em cada momento histórico de cada povo. Tomando como paradigma o direito de propriedade depois da Revolução Francesa, encontramos um conceito que podemos chamar de clássico (que apontamos em alguns de nossos autores no item 3.5 supra) e um conceito que podemos chamar de contemporâneo. Mas, devemos estar atento, ao tentar defini-lo, porque não "existe um conceito inflexível do direito de propriedade." 93 Além disso, por vezes esquecemos que na interpretação da norma jurídica, deve-se buscar sempre seu sentido atual, seus "conteúdos novos", ${ }^{94}$ pois o texto nada mais é do que um complexo de palavras, "a casca exterior que encerra um pensamento, um conteúdo espiritual", ${ }^{95}$ haja vista, sua constante evolução, respondendo pelas novas necessidades e pelos novos problemas jurídicos decorrentes da mudança do tempo, com significações novas, que, quando de sua edição, sequer podia pensar nelas.

92 TRABUCCHI, Alberto. Istituzioni di Diritto Civile. Padova: Casa Editrice Dott Antonio Milani, 1978, p. 410.

93 PEREIRA, Caio M. da S. Instituições de Direito Civil. v. IV, Forense, RJ, 2003, p. 81, atualizada pelo eminente professor, meu dileto amigo e colega de cadeira na Faculdade de Direito da Uerj, Carlos Edison do R. Monteiro.

${ }^{94}$ ANDRADE, Manuel A. Domingues. Ensaio sobre a Teoria da Interpretação das Leis. 3. ed., Coimbra: Armênio Amado, 1978, p. 19.

${ }^{95}$ FERRARA, Francesco. Interpretação e Aplicação das Leis. 3. ed. Coimbra: Armênio Amado Editor, 1978 , p. 127-128. Por sua vez, Clovis Bevilaqua, afirma que "interpretar a Lei é revelar o pensamento, que anima suas palavras". Teoria Geral, 2. ed., Livraria Francisco Alves, 1929, p. 48. 
Neste passo é bom lembrar-se das palavras de Duguit de que as leis positivas, os códigos, podem permanecer intactos em seus textos rígidos: "poço importa; por la fuerza de lãs cosas, bajo la presión de los hechos, de las necesidades prácticas, se forman constantemente instituciones jurídicas nuevas." O texto está sempre ali, porém caído sem força e sem vida, mas por uma exegese sabia e sutil, "se lê da um sentido y um alcance em los cuales no había somado el legislador cuando lo redactaba." ${ }^{96}$ Em sentido semelhante Karl Engish, assinala que as modificações das situações de fato, das concepções culturais e morais conduzem, mesmo sem uma lei posterior, a uma releitura da legislação anterior não revogada. $^{97}$

De regra, como adverte Rodotá os conceitos clássicos do direito de propriedade partem, com maior ou menor variação, do exame do conteúdo e dos poderes do proprietário e podem ser resumidos na fórmula seguinte: a propriedade (ou o poder do proprietário) consiste na possibilidade de fazer do objeto tudo aquilo que não está vedado por lei. ${ }^{98}$ Essa visão dos autores, não raro, parte do exame do direito positivo, indicando-se como ponto de partida o Código Civil Francês no seu art. 544.

Para Radbruch a regulamentação das relações entre os homens não pode deixar de envolver também uma regulamentação das relações entre os homens e as coisas. Para o filósofo alemão o direito de propriedade é um direito subjetivo "que habilita o seu titular a dispor da coisa sem limitações, ou seja, um direito a proferir a última palavra acerca da coisa." ${ }^{99}$ Bevilaqua define a propriedade "como sendo o poder assegurado pelo grupo social à utilização dos bens de vida psíquica e moral." ${ }^{100}$ Para PACIFI-MAZONNI, a

${ }_{96}^{96}$ UGUIT. Leon. Las Transformaciones genereles del Derecho privado desde el Código de Napoléon. Trad. Carlos Posada, 2. ed. Madrid: Francisco Beltran, 1920, p. 19.

${ }^{97} \mathrm{ENGISH}$, Karl. Introdução ao pensamento jurídico. 6. ed. Lisboa: Fundação Calouste Gulbenkian, 1988, p. 322.

${ }^{98}$ RODOTÁ, Stefano. El terrible derecho: estúdios sobre la propriedad privada. Trad. Luiz DíezPicazo. Madri: Civitas, 1986, p. 264.

${ }^{99}$ RADBRUCH, Gustav. Filosofia do Direito. Trad. de L. Cabral Moncada. Coimbra: Armênio Ed., 1979, p. 267-268.

100BEVILAQUA, Clovis. Direito das Coisas..., ob. citada, p. 111. 
"proprietà è un diretto na virtiu del quale uma cosa corporale si trova soltomessa nella maniera piu assoluta ed esclusiva alla volontà e all'azione della persona che n'è investita". ${ }^{101}$

Embora se tenha atribuído ao direito de propriedade o caráter de absoluto ${ }^{102}$ apesar de alguns afirmarem não ser esta a característica maior do direito de propriedade como direito real, uma vez que todos os direitos oponíveis erga omnes são considerados como absolutos $^{103}$ e assim também o são os direitos, v.g. da personalidade, os de família puros. ${ }^{104}$ Segundo o magistério de Moreira Alves, em Roma a propriedade já continha limites, ${ }^{105}$ assegurando Cretella Junior que "o traço individualista dos primeiros tempos vai sofrendo contínuas atenuações, cedendo lugar à penetração do elemento social." 106

Este aspecto foi ressaltado por Kelsen ao afirmar que mantida a definição tradicional de propriedade como domínio exclusivo de uma pessoa sobre uma coisa, a relação juridicamente essencial, isto é, à sua função econômico-socialmente decisiva será ignorada. $^{107}$

Na realidade, hoje em dia não se pode mais conceber o direito de propriedade com a feição de outrora, sendo necessário superar a visão clássica, na qual o interesse do proprietário é o objeto central da tutela, para em verdade mudar o foco, para considerar sua proteção como a proteção de apenas um interesse, num "quadro complexo de outros interesses contrastantes, que o ordenamento reconhece e também tutela." 108

Veja-se a propósito a opinião de Salvatore Pugliatti na seguinte passagem:

${ }^{101}$ MAZZONI. Emidio Pacifici. Instituzioni di Diritto Civile Italiano. 3. ed. vol. IlI. Firenze Ed., Eugenio e Filippo Cammelli. 1884, p. 98.

${ }^{102}$ Qualificação contestada por Clovis Bevilagua, que sustenta que todos os direitos são relativos. (D. das Coisas, ob. citada, p. 263). A idéia de propriedade com característica de absoluta, decorreu, segundo Arruda Alvim, dos art. 554 e 555 do C. Civil Francês, por se interpretar que o proprietário podia inclusive "abusar" de seu direito de proprietário (Posse e Propriedade. São Paulo: Saraiva Ed., 1987, p. 45).

103BEVILAQUA, Clovis. Direito das Coisas..., ob. cit., p. 263.

${ }^{104}$ PEREIRA, Caio Mario da S. Instituições de D. Civil. 9. edição. vol. Ol. Rio de Janeiro: Forense Ed., p. 33.

105ALVES, José Carlos M.. Direito Romano. 9. ed. vol I. Rio de Janeiro: Forense Ed., 1995, p. 285-289. 106JUNIOR, J. Cretella. Curso de Direito Romano. 11. ed. Rio de Janeiro: Forense Ed., I987, p. 173. 107KELSEN, Hans. Teoria Pura do Direito. Trad. João Batista Machado. Ed. Martins Fontes, 1985, p. 144.

108LOUREIRO, Francisco E. A Propriedade como Relação Jurídica Complexa. Rio de Janeiro-São Paulo: Renovar, 2003, p. 46. 


\begin{abstract}
"La proprietà oggi non è proprietà (esclusivamente) individuale, ma è pur sempre propreità dell' individuo; è, sotto ogni aspetto, proprietà privata, ma attegiata ed orientata in modo da consentire la più idonea tutela dell' interesse pubblico."

"Non conserva però il carattere spiccatamente individualistico della proprietà tradizionale perchà se fondamentalmente e garanzia dell' attuazione di un interesse che è del singolo proprietário, constituisce anche uno dei mezzi più largamente impiegabili per l'attuazione di interessi che transcendono la sfera individuale. " 109
\end{abstract}

Aliás, mesmo sob a égide das teorias individualistas, a propriedade nunca foi rigorosamente individualista, pois se assentava "no pressuposto duma harmonia preestabelecida entre o interesse individual e a utilidade geral", assegurando Radbruch, que "somente com a Encíclica Papal Quadragésimo ano, que a teoria social de propriedade alcançou uma feição autoritária". ${ }^{110}$

Creio que a idéia de "absoluto" no direito de propriedade, não tem ou nunca teve, mesmo nos tempos áureos do individualismo inspirador do movimento de codificação do século passado, a força para suplantar a ordem jurídica. Seria admitir, a contragosto de Sá Pereira, que a idéia romana de propriedade, encarnava "um direito fora e acima da sociedade, num esplêndido isolamento, apenas sujeito à satisfação de interesses individuais". ${ }^{111}$ No mesmo sentido escreve Maria Pezzella salientando ser um equívoco atribuir ao direito romano a origem da propriedade como um poder ilimitado, haja vista que esta construção deve ser atribuída ao regime jurídico da propriedade posteriormente construído. ${ }^{112}$ Quanto a este ponto Ihering assinala que os romanos tinham plena consciência dos perigos existentes na realização insensata da concepção abstrata, formalista do instituto da propriedade (dominio absoluto da coisa). ${ }^{113}$

Procurando demonstrar a relativização da propriedade Scialoja, a define como sendo "uma relação de direito privado, pela qual uma coisa como pertence de uma pessoa é completamente sujeita à sua vontade em tudo que não seja vedado pelo direito público ou

109 PUGLIATTI. La Proprietà nel Nuovo Diritto. Milano: Dott. A. Giuffré Ed., 1964, p.107

110 RADBRUCH, Gustav. Filosofia do Direito. Tradução de L. Cabral Moncada..., ob. cit., p. 278 Ver no mesmo sentido ARRUDA ALVIM. Breves Anotações para uma Teoria Geral dos Direitos Reais, in Posse e Propriedade. São Paulo: Saraiva Ed., 1987, p. 45.

111 PEREIRA, Virgílio de Sá. Direito das Coisas. vol. VIII. Jacintho Ribeiro dos Santos, 1924, p. 8. 112 PEZZELLA, Maria Cristina Cereser. Propriedade Privada no Direito Romano. Porto Alegre: Sergio A. Fabris Editor, 1998, p. 125.

113 IHERING, Rudolf von. A Finalidade do Direito. Tomo I. Trad. Heder K. Hoffmann, 1. ed. São Paulo: Bookseller Editora e Distribuidora, p. 348. 
pela concorrência do direito alheio" ${ }^{114}$ Para Ruggiero esta é a melhor definição do direito de propriedade, opinião que é seguida por Serpa Lopes. ${ }^{115}$

Esta questão não é só acadêmica, mas sim de grande interesse prático face as consequiências que produz considerar a propriedade como um direito ilimitado do titular, ignorando o impacto que tal reconhecimento traria para a sociedade atual. Neste passo podese trazer como exemplo trecho da ementa de um julgado do STF da lavra do Min. Celso Mello: "O direito de propriedade não se reveste de caráter absoluto, eis que, sobre ele, pesa grave hipoteca social, a significar que, descumprida a função social que lhe é inerente $(\mathrm{CF}$, art. 5 XXIII), legitimar-se-á a intervenção estatal na esfera dominial privada, observados, contudo, para esse efeito, os limites, as formas e os procedimentos fixados na própria Constituição da República". ${ }^{116}$

Para conceituar a propriedade contemporânea devemos ter como meta um conceito aberto, atemporal, necessariamente axiológico, que se densifica, adquirindo concretização, ${ }^{117}$ uma vez que a função social que lhe é inerente não tem natureza de principio programático e nem de limite exterior ao direito, mas integra sua estrutura como preconiza a boa doutrina, de forma que sua ausência traz conseqüência para o próprio conceito, situação que poderá ser identificada como uma outra forma de apropriação mas não direito de propriedade. ${ }^{118}$

${ }^{114}$ Apud RUGGIERO, Roberto de. Instituições do Direito Civil. Vol. 2. São Paulo: Saraiva Ed., 1972, p. 300.

115 LOPES, Miguel M. de S. Curso de Direito Civil. V. VI, 2. ed. Rio de Janeiro-São Paulo: Livraria Freitas Bastos S/A, 1962, p. 227.

116 Trecho da Ementa da ADI 2213 MC, Rel. Min. Celso de Mello, Tribunal Pleno, julgado em 04.04.2002, DJ 23.04.2004.

117 ARONNE, Ricardo. Propriedade e Domínio. Reexame Sistemático das Noções Nucleares de Direitos Reais. Renovar, p.152.

${ }^{118}$ Pode-se afirmar, com uma boa margem de segurança, que a doutrina é quase unânime em reconhecer que a função social não é limite ao direito de propriedade, mas faz parte de seu conteúdo, fundindo-se "com o próprio núcleo do conceito de propriedade." (BASTOS, Celso R. A função social como limite constitucional ao $D$. de Propriedade. Revista de Dir. Constitucional e Ciência Política. $\mathrm{n}^{\circ}$. 6 , vol. 4 , 1988, p. 25). O princípio da função social da propriedade "se erige numa das vigas mestras de nossa ordem econômica e social" (BASTOS, Celso R. e MARTINS, Ives Gandra. Comentários à Constituição do Brasil. São Paulo: Saraiva Ed., 1989, p.122) e, outros, já afirmam que é mais provável ser a propriedade uma função social, do que ter a propriedade uma função social (BEZERRA, 
Para Pugliatti, pode-se dizer que a propriedade, se já não é, está em via de ser, instrumento de realização de uma complexa e poliédrica função social e que o impulso a tal radical transformação de sua estrutura e de sua natureza, opera já de acordo com o ordenamento jurídico e com força jurídica apta para atuação. ${ }^{119}$

Rodotà afirma que "la función social debe considerarse como componente de la estructura de la propriedade, los datos reconducibles a ella (deberes y cargas que gravan al titular) no se pueden colocar en el exterior de la situación como límites de derecho publico ou de cualquier otro modo que se quiera considerarlos."120

Perlingieri sustenta que "la teoria dei limiti non è qualcosa che sta al di fuiri della strutura della proprietà, non é un profilo esterno alla proprietà, ma costituisce uno dei piú pregnanti contenuti del diritto di prorpietà. Questo stesso discorso può esser fatto, del resto, per qualsiasi diritto soggettivo: anche altre situazioni giuridiche soggettive hanno limiti, vincoli, oneri, i quali fanno parte di quella situazione giuridica soggettiva complessa, incidendo sul contenuto dall'interno e non dall 'esterno."121

Com acerto salienta Aronne que urge uma completa reconceituação da propriedade, para que bem "se apanhe o instituto como redesenhado no sistema jurídico e redefinido, em seus parâmetros" ${ }^{122}$, daí porque apropriada nos parece a definição trazida por Francisco Loureiro, quando afirma que propriedade é a "relação jurídica complexa que tem por conteúdo as faculdades de uso, gozo e disposição da coisa por parte do proprietário, subordinadas à função social e com correlatos deveres, ônus e obrigações em relação a terceiros." 123

Raimundo Falcão. A função social da propriedade. São Paulo: RDA, vol. 55/56, p. 311, destaque no original) , que já nasceria com ela. Quanto a este ponto e outros aspectos relativos à função social da propriedade, consulte nosso estudo: "A propriedade e a posse: um confronto em torno da Função Social', Rio de Janeiro: Lúmen Júris Editora, 2007.

119 PUGLIATTI, Salvatore. La Proprietá Nel Nuovo Diritto, Milano, Dott. A. Giuffrè Editore, 1964, p. 278.

120 RODOTÀ, Stefano. El Terrible Derecho ...ob cit p. 221.

121 PERLINGIERI, Pietro. Introduzione a la problemática... ob cit. p. 121.

${ }_{122}$ ARONNE, Ricardo. Propriedade e Domínio. Reexame Sistemático das Noções Nucleares de Direitos Reais. ob. cit. p. 173.

123 LOUREIRO, Francisco E. A Propriedade como Relação Jurídica Complexa. Rio de Janeiro-São Paulo: Renovar, 2003, p. 52. 


\section{5 - A Multiplicidade dominial.}

Embora pareça contraditório terminar o tópico antecedente apresentando uma definição do direito de propriedade que implica na apresentação de um conceito genérico, com idéia de totalidade e abrangência, e logo a seguir falar de "direitos de propriedades", em verdade, o reconhecimento da multiciplidade dominial não afasta a possibilidade de construção de um conceito para o instituto como se verá. Com efeito, um conceito unitário à maneira oitocentista não lograria regular o direito de propriedade sobre os diversos bens que lhe servem de objeto, levando em conta as prerrogativas e obrigações do titular do direito, que flutuam conforme a natureza e as características do objeto e conforme a pessoa do titular.

Falar em "propriedades" sugere num primeiro momento uma pluralidade de propriedades no sentido de uma soma de propriedades individuais ou uma concentração de propriedades num mesmo titular, fruto da noção unitária de propriedade, que na era moderna nos foi legada pelo código civil francês, com a concentração de poderes em mãos de um único titular. Pode-se também imaginar que se trata de co-propriedade, isto é, mais de um titular do direito de propriedade sobre um mesmo bem. No entanto, ainda que se olhe para o bem objeto do direito, o sentido é bem outro. Na verdade está-se falando do mesmo direito, isto é, do direito de propriedade, mas que apresenta peculiaridades de regulação não só em razão do objeto, mas também em razão do titular do direito, com interferências nas características básicas deste direito, ora afetando o poder de disposição, ora impondo a prática de atos, ora restringindo ou estabelecendo a forma de utilização, formando autênticos núcleos ou feixes de direitos e obrigações, decorrente da natureza complexa do direito de propriedade como acima se viu. Lembre-se por ex., a impossibilidade de disposição por um certo tempo de terras recebidas de reforma agrária, a limitação do gozo da coisa, imposta a propriedade localizada em área de proteção ambiental ou ainda a impossibilidade de divisão de imóvel rural em áreas inferiores ao modulo rural (art. 65 do Estatuto da Terra).

Se fixarmos os olhos na diversidade de tratamento dado à propriedade pela constituição federal perceberemos a necessidade de confronto do conceito unitário com a nova realidade e a insuficiência da visão unitária para solução das diversas questões oriundas do mesmo fenômeno jurídico. Esse confronto pode produzir conceitos novos ou a reconstrução do conceito para adequá-lo às novas realidades. A reconstrução de uma noção 
plural do direito de propriedade, é uma forma de superação teórica do "quadro erigido no decorrer do procedimento codificatório" como assinala Laura Varella e Marcos Ludwig. ${ }^{\mathbf{1 2 4}}$

Com efeito, no desenvolvimento da noção de propriedade vimos que a propriedade individual, tratada como direito subjetivo não era uma noção tão antiga assim, nem tanto pelo direito de propriedade mas sim pela construção do conceito de direito subjetivo. Fustel de Coulanges salienta que não podemos formar a idéia da instituição propriedade dos antigos com base na idéia moderna que temos, haja vista que os antigos se basearam em princípios diferentes e com leis sensivelmente diversas das nossas leis. ${ }^{\mathbf{1 2 5}}$ Mas o fato é que a propriedade chegou da antiguidade até a idade média como um conceito unitário. Após a queda do império Romano, com o surgimento da propriedade feudal, surgiu a propriedade divida segundo John Gilissen ${ }^{\mathbf{1 2 6}}$ em dominio eminente e dominio útil. Um com a propriedade estática, formal, destituído da possibilidade de utilização da coisa e outro com a "propriedade de fato", propriedade dinâmica, com o gozo e utilização da coisa, mas com compromissos e deveres em relação ao titular da propriedade formal. Quebrou-se aí a noção unitária da propriedade, criando-se "domínios" concorrentes sobre o mesmo bem, fundado na utilização da coisa para um e na concentração de poderes para outro, além da prerrogativa de exigir algumas prestações e deveres do outro. ${ }^{\mathbf{1 2 7}}$

A multiplicidade dominial também pode ser percebida no regime de exploração das terras conhecido por sesmarias, implantado por Portugal tanto lá, com base na Lei de 26.06.1375 de D. Fernando, quanto aqui com base nas Ordenações do Reino (Afonsinas de 1446, Manuelinas de 1521 e Filipinas de 1603), em que o sesmeiro recebia a

124 VARELA, Laura B. e LUDWIG, Marcos de C. Da Propriedade às Propriedades: Função Social e Reconstrução de um Direito. In A Reconstrução do Direito Privado. Org. Judith Martins-Costa. Editora Revista dos Tribunais, 2002, 764.

125 COULANGES, Fustel. $A$ cidade antiga...ob cit. p. 82.

126 GILISSEN, John. Introdução Histórica ao Direito. Trad. A.M.Hespanha. Lisboa: Fundação Calouste Gulbenkian, 1979, p. 640-645.

${ }^{127} \mathrm{Cf}$. Burns o feudalismo foi um prolongamento das antigas instituições romanas, dentre elas a "clientela", do "colonato" e do "precarium" que com o declínio do império romano foram se ampliando. Mais tarde o "precarium" assumiu a forma de entrega da terra por um proprietário pequeno a um poderoso magnata, por causa da insolvência ou necessidade de proteção. O "colonato" e o" precarium" muito contribuíram para o desenvolvimento de um feudalismo extralegal na antiga história romana.BURNS, Edward Mcnall. História da Civilização Ocidental. $2^{\circ}$ vol. Trad. Alexandre Costa. Rio de Janeiro: Ed. Globo S/A, 1980, p. 12. 
posse de terras públicas em concessão para explorá-las, evidenciando a existência de um proprietário formal, a Coroa Portuguesa e um proprietário de fato, o sesmeiro que explorava a terra e que tinha obrigação de explorá-la como condição de manutenção de seu próprio direito. Aliás, a função básica do instituto da sesmaria é permitir o exercício da posse da terra, enfim da função social da terra, como bem de produção primário, não só no interesse do titular, mas também no interesse da coletividade. Esta a razão da edição da Lei pelo Rei D. Fernando. $^{128}$

Mas numa visão moderna do fenômeno da vinculação das coisas ao homem, que chama de titularidade, Perlingieri, reconhece a distinção, ainda que não propriamente técnica, de uma titularidade formal e uma titularidade substancial, que inspira-se na quantidade de poder que um determinado sujeito tem, situação especialmente reconhecida no direito de propriedade. Hipótese que ocorre quando se reconhece a um sujeito a titularidade (formal) da situação enquanto que o conjunto de poderes e faculdades que correspondem a seu conteúdo seja atribuído a outros ou mesmo seja excluído por lei. Salienta referido autor que existem situações nas quais um sujeito é, para certos fins, considerado proprietário, titular (formal) da situação proprietária, mas se encontra privado, às vezes irreversivelmente, dos direitos ou dos poderes característicos da propriedade. Por vezes está impedido de dispor do bem, por ex., quando se trata de bem de grande valor artístico e outras vezes, é negada faculdade de gozo, eis que o gozo efetivo está atribuído por lei a outros. Estes assumem substancialmente os poderes e direitos ou a maior parte deles, que são típicos do proprietário, apesar de não serem proprietários. Tem nesta hipótese uma titularidade substancial. Modernamente esta situação encontra-se na enfiteuse. ${ }^{129}$

A observação quanto a insuficiência do conceito unitário do direito de propriedade, oriundo da codificação, foi apontada, em 1935, num Congresso de Direito Agrário ocorrido na Itália por Enrico Finzi com o tema: "Dritto di proprietá e disciplina della produzione", e por Salvatore Pugliatti com o tema: "Interesse pubblico e interesse privato nel diritto di proprietá", tendo mais tarde, no Terceiro Congresso de Direito Agrário, realizado em

\footnotetext{
${ }_{128}$ Para saber mais sobre o instituto que dera origem às sesmarias e sua utilização em Portugal e nas terras conquistadas, consulte nosso estudo " $A$ Propriedade e a Posse", Rio de Janeiro: Lúmen Júris Editora, item 1.4, p. 17-25.

129 PERLINGIERI, Pietro. Perfis do Direito Civil. Introdução ao Direito Civil Constitucional. Trad. Maria Cristina De Cicco. Rio de Janeiro: Renovar, 1997, p. 109-110.
} 
1952, este último autor apresentado o trabalho sistematizado sobre o assunto que tornou-se ponto de referência com o titulo: "La proprietá e le proprietá."130

No mesmo sentido, também se posicionou Antonio Gambaro, afirmando que o debate em torno do significado da expressão propriedade, ocorrera, na Itália, pelos anos trinta, chegando-se à conclusão, que " il concetto classico non pùo essere utilizzato come fonti di princìpi e regole in materia proprietaria". ${ }^{131}$

Há multiplicidade dominial que varia conforme a natureza do bem e sua destinação econômica e social e multiplicidade dominial que varia conforme o titular. $\mathrm{O}$ reconhecimento da noção pluralista do direito de propriedade implica no nascimento de diversos estatutos proprietários, evidenciando e moldando a particularidade proprietária de cada situação.

Pugliatti cuidou da questão das diferentes propriedades separando o tratamento em relação aos sujeitos e em relação ao objeto. Ao primeiro chamou de perfil subjetivo e assim considerou por ex. o exame da propriedade publica e da propriedade privada, entre a propriedade plena e a co-propriedade, pontuando as diferenças qualitativas e quantitativas. $\mathrm{Na}$ propriedade publica há também distinções próprias como bens de uso comum, bens de uso especifico e bens dominicais. Quanto ao perfil objetivo cuida da distinção entre propriedade substancial e propriedade formal, indicando como ex., o concessionário perpétuo de imóveis públicos, do enfiteuta. ${ }^{132}$

Atento a estas transformações Ricardo Lira acentua que "a rigor, não há que falar só em redefinição da propriedade, mas em diversificação do direito de propriedade, no seu conteúdo, conforme o bem da vida que esteja em jogo, visando à função social da propriedade, como um dos instrumentos da Justiça Social."

Diez-Picazo afirma que os partidários da tese da multiplicidade de propriedades, sustentam a desintegração do conceito unitário e a diversificação dos regimes jurídicos. O conceito unitário deixa espaço para a idéia de diversidade de propriedades, já que segundo a natureza do objeto, a situação jurídica deverá ter conteúdo diferente. ${ }^{134}$

\footnotetext{
130 GROSSI, Paolo. La propiedad e las propiedades. ob cit. p. 19-20.

131 GAMBARO, Antonio. Jus Aedificand e Nozonie Civilistica della Proprieta. Giuffaè Editore, 1975, p. 398. 132 PUGLIATTI, Salvatore. La Proprietá Nel Nuovo Diritto. ob. cit. 233-245.

133 LIRA, Ricardo Pereira. Elementos de Direito Urbanístico. Rio de Janeiro: Renovar, 1997, p. 161. 134 PICAZO, Luiz Díez. In Prólogo ao El Terrible Derecho de Stefano Rodotá, ob cit. p. 16.
} 
Não se pode, aplicar as mesmas diretrizes, os mesmos esquemas, do regime da propriedade móvel à propriedade imóvel, da propriedade urbana à propriedade rural, da propriedade de bens de produção à propriedade de bens de consumo, da propriedade pública à propriedade privada, da propriedade pública dominical à propriedade pública de bens de uso específico e de bens de uso comum do povo, da propriedade à co-propriedade e assim sucessivamente. Há, segundo os partidários da tese da multiplicidade "estatutos de propriedade". 135

Vicenzo Caputi salienta que toda a doutrina sobre a propriedade privada chegou a um consenso em decorrência dos diversos poderes do proprietário sobre a coisa, provocando uma pluralidade de tipos jurídicos de propriedades." ${ }^{136}$ Tal construção, na lição de Tepedino, é fundamental "para a compreensão das inúmeras modalidades contemporâneas de propriedade e serve de moldura para uma posterior elaboração doutrinária."137

De fato, ressente a doutrina, em especial aquela exteriorizada nos manuais (com raras exceções) com reflexos indubitáveis nos ensinamentos universitários do enfoque plural a influenciar no próprio conceito em discussão. Não se deve mais falar em propriedade, mais sim em propriedades.

Segundo José Afonso da Silva "uma coisa é a propriedade pública, outra a propriedade social e outra a privada; uma coisa é a propriedade agrícola, outra a industrial; uma, a propriedade rural, outra a urbana; uma, a propriedade de bens de consumo, outra, a de bens de produção; uma, a propriedade de uso pessoal, outra a propriedade/capital."138

Mas, a noção unitária arraigada nos códigos, inspira todo um segmento de investigadores, ignorando a insuficiência de tal visão, cujo dado objetivo é perfeitamente verificável na disciplina proprietária do documento normativo maior - a Constituição.

Separou o legislador constitucional, com implicações diversas, a disciplina da propriedade urbana e da propriedade rural, não só no que diz respeito ao conteúdo do direito mas também quanto a específica função social de cada um. Também cuidou da propriedade de

135 PICAZO, Luiz Díez. In Prólogo ao El Terrible Derecho de Stefano Rodotá. ob cit. p. 16.

136 JAMBRENGHI, Vicenzo Caputi. Proprietà Privata (Disciplina Amministrativa) in Digesto delle Discipline Pubblicistiche. v. XII, Utet., 4. ed, 1987, p. 112.

137 TEPEDINO, Gustavo. Contornos Constitucionais da Propriedade Privada. In Temas de Direito Civil. Renovar, 1999, p. 279.

138 SILVA, José Afonso da. Direito Urbanístico Brasileiro. 2. ed. Malheiros Editores, 1995, p. 64. 
empresas que exploram atividades jornalísticas, de empresas atuam na extração de riquezas naturais.

Pugliatti, na parte ainda inicial de seu estudo, lança uma fórmula que chama de sugestiva e que confere um relevo particularmente acentuado à propriedade: "Sembra corrispondente allo stato attuale delle leggi, le quali hanno disciplinato in vario modo i poteri del proprietario, riconoscere che non vi è una sola proprietà, che vi sono piuttosto delle proprietà." 139

Reconhece o autor que, na fórmula acima, se mantém o equilíbrio entre a unidade do conceito e as variedades de aspectos específicos que ele assume, mas que o problema permanece e se põe decisivamente quando se observa a disciplina positiva da propriedade, não sendo razoável falar de um só tipo, mas sim de diversos tipos de propriedade, cada qual assumindo um aspecto característico. Assim, não é razoável afirmar que a multiplicidade de aspectos não compromete a unidade conceitual. ${ }^{140}$

Ao final de seu estudo, conclui Pugliatti:

La risposta al quesito che ci siamo proposti all'inizio sta nell'analisi che abbiamo condotta e potrebbe trovare specifica conferma in quella che altri vorrà condurre. Qui in sintesi e a suggello del lungo discurso, possiamo dichiarare che la parola 'proprietà' non ha oggi, se mai ha avuto, un significato univoco. ${ }^{141}$

Tal conclusão inspirou a doutrina futura, como se pode observar na lição de Perlingieri: "non esiste cioé un ùnica proprietà, non esiste una nozione rigida, difinita di proprietà", o que significa "che non è piu possibile discorrere di unità del dominio", pois "esiste una pluralità di domini."142

Rodotá reconhece que não se chegará a conclusões diversas se aceitarmos os resultados das investigações que, se realizado com dimensão histórica, comprovar-se-á que de baixo da casca da definição unitária, se tem mantido em todo momento disciplinas setoriais fortemente diferenciadas e conclui:

No es posible limitarse a "rasgar el velo" de la propiedad única: subsiste siempre la necesidad de explicar cómo ha podido acreditarse durante decenios la tesis de la

\footnotetext{
139 PUGLIATTI, Salvatore. La Proprietá Nel Nuovo Diritto. Milano: Dott. A. Giuffrè Editore, 1964, p. 148. Grifos nossos.

140 Ibidem, p. 149.

141 Ibidem, p. 309.

142 PERLINGIERI, Pietro. Introduzione Alla Problematica Della Proprietà. Jovene Editore, 1970, p. 59.
} 
unidad del concepto de propiedad no obstante la existencia de disciplinas sectoriales diferenciadas. ${ }^{143}$

Paolo Grossi assinala que havia germinado uma intuição elementar de que estava na hora de examinar a relação entre os homens e as coisas, observando a relação sem os preconceitos individualistas e com uma disponibilidade total para ler as coisas sem óculos deformadores. Salienta ainda, que as coisas se tinham revelado como estruturas não genéricas, mas sim específicas, com ordens específicas e diversificadas, reclamando diversas e particulares construções jurídicas e remata:

De los diversos estatutos de los bienes se había llegado a la edificación de una pluralidad de propiedades, cada una de las cuales tenia un fundamento estructural basado en la recuperada realidad de los hechos naturales y económicos. Lo que importa aquí poner de relieve es que, por primera vez después del énfasis del individualismo posesorio, el individuo dejaba de ser el eje de la noción de propiedad, se intentaba una construcción partiendo de elementos objetivos, y, en consecuencia se la relativizaba. ${ }^{144}$

O reconhecimento da multiplicidade de estatutos proprietários possibilita a quebra da absolutização da propriedade, produto histórico de uma época, uma vez que o modelo "antropológico napoleônico-pandectista", consagração da visão individualista, "é apenas um dentre as múltiplas respostas encontradas nas múltiplas experiências jurídicas do passado e do presente", decorrente da "eterna questão dos vínculos jurídicos entre homem e as coisas." 145

O conceito unitário formal e abstrato, é inadequado para descrever "a complexidade das múltiplas formas de apropriação da terra que antecederam a formulação unitária, correspondente ao período das codificações" e nem corresponde aos modelos atuais. Há previsão de diversos estatutos proprietários "de acordo com a potencialidade econômica da propriedade, levando-se em conta sua destinação." 146

Além da dimensão social de utilização - propriedade urbana ou rural - outra classificação importante demonstra a insuficiência do conceito unitário consagrado nos códigos: a distinção entre bens necessários à produção de outros bens e bens destinados ao uso e consumo do indivíduo.

\footnotetext{
143 RODOTÁ, Stefano. El terrible... ob cit. p. 50-51.

144 GROSSI, Paolo. La propieda ... ob. cit. p. 21.

145 VARELA, Laura Beck. Das Propriedades ã Propriedade... ob.cit. p. 732.

146 TEPEDINO, Gustavo. Contornos... ob. cit., p. 270-271.
} 
Em 1970, Orlando Gomes publicou artigo sob o título: "Novas Dimensões da Propriedade Privada", reconhecendo a existência de diversos modelos proprietários e a insuficiência do conceito unitário estabelecido pela civilística do século anterior, escrevendo:

Falta, porém, a necessária síntese, a construção dogmática que concilie tantas contradições e permita se venha a estampar no Código de Direito Privado a imagem verdadeira da relação jurídica multiforme que o particular pode constituir para aproveitamento econômico de seus bens, de sorte que não continue a ser disciplinada como se exaurida no uniforme tratamento da propriedade dos bens de uso e de consumo.

Em suma, uma construção, espaçosa e arejada, que abrigue todos os modos por que se permita no Ocidente a satisfação do interesse individual da apropriação e utilização dos bens de todas as espécies, conserve-se, ou não, o nome tradicional de propriedade, nesse caso com os qualificativos adequados. ${ }^{147}$

No seu manual, o eminente civilista cuidou separadamente da propriedade imóvel urbana e rural, analisando as peculiaridades de cada uma, reconhecendo para a propriedade urbana um novo conceito e para a propriedade rural a sua fuga do Código Civil para o Estatuto da Terra. ${ }^{148}$ Ainda não existia, salvo em projeto, o Estatuto da Cidade, evidenciando a multiplicidade de formas dominiais, cada qual com sua peculiaridade, influenciando na sua conceituação e moldura, decorrentes de sua função social e econômica.

A Constituição estabeleceu parâmetros de caracterização funcional da propriedade, tanto urbana quanto rural, mas tais parâmetros, não esgotam a dimensão proprietária urbana ou rural, consoante regras estabelecidas na legislação infra-constitucional.

Quando a constituição impõe ao proprietário urbano a utilização do bem objeto de seu direito atendendo as exigências fundamentais de ordenação da cidade (cf. $\S 2^{\circ}$ do art. 182 da C.F.) como condição para cumprimento da função social, está pensando na coletividade resultante da cidade nas suas diversas peculiaridades, considerando um "momento coletivo" do direito de propriedade. Quando outorga ao Poder Público municipal o direito de exigir do titular do direito de propriedade urbana o parcelamento do solo e a edificação (cf. $\S 4^{\circ}$ do art. 182 da C.F.) também está reconhecendo a necessidade de atendimento de interesses outros que não somente os do proprietário, considerando que o parcelamento visa à uma melhor distribuição do solo, de regra com alienação das parcelas para àqueles que dele necessitam para morar ou empreender atividade econômica e, do

\footnotetext{
147 GOMES, Orlando. Novas Dimensões da Propriedade Privada. RT 411, 1970, p. 14. 148 Idem, Direitos Reais. 13. ed. Rio de Janeiro: Ed. Forense, 1998, p. 102-106.
} 
mesmo modo a edificação, conforme a capacidade construtiva do imóvel e a natureza da edificação.

Seguindo a diretriz constitucional em relação à propriedade imóvel urbana, aprovou o legislador documento legislativo que por força da própria lei passou a chamar-se de Estatuto da Cidade (Lei 10.257/2001), trazendo institutos estranhos à propriedade regulada pelo então vigente código civil, evidenciando a incapacidade da lógica dominical então em vigor, tais como: o solo criado, o direito de superfície, concessão de uso especial para fins de moradia, direito de preempção, e quebrando um sistema tradicional e histórico para admitir a usucapião coletiva, além de regular os institutos do parcelamento e edificação compulsórios, do IPTU progressivo e da desapropriação sanção estabelecidos na C. Federal. Saliente-se que criou uma hipótese de obrigação "proter rem" fora do tradicional direito civil, ao fixar a deambulação da obrigação de edificar, parcelar ou ambas, com a titularidade (art. $6^{\circ}$ ).

Permitiu a lei em questão à interferência no conteúdo do próprio direito de propriedade num dos aspectos de maior relevância para o imóvel urbano, qual seja, o seu potencial construtivo. Não há dúvida que o imóvel urbano, por sua própria natureza só tem vocação para edificação, tomando a expressão em amplo sentido. $\mathrm{O}$ valor de mercado de um imóvel certamente variará conforme a possibilidade de sua exploração econômica. $\mathrm{Na}$ hipótese de construção de edificações o controle das dimensões de utilidade, altera substancialmente o valor econômico do resultado. Por certo que limites administrativos sempre existiram neste tema e de regra, de modo regionalizado. No entanto, com natureza jurídica distinta dos tradicionais limites administrativos, possibilita o Estatuto a alteração do conteúdo mesmo do direito de propriedade quando permite, observados os requisitos na lei estabelecidos, a fixação de coeficientes de aproveitamento do solo ( $\$ 1^{\circ}$ do art. 28), transferindo para o poder público, como propriedade nova e autônoma, o potencial construtivo do imóvel. Além disto, criou a possibilidade de alienação pelo proprietário deste potencial construtivo quando, por interesses outros da coletividade, como históricos, culturais, paisagístico, sociais, ambientais, não puder ele exercer no seu imóvel o seu direito de construir, numa forma de compensação pelo ônus imposto a tal direito em prol de interesse que a rigor não é seu, mas sim da coletividade. Possibilitou a interação entre a propriedade privada e a pública através das operações urbanas consorciadas, permitindo ao proprietário privado ou público a alienação do resultado obtido.

$\mathrm{Na}$ verdade trouxe muito mais obrigações, ônus e sujeições do que direitos para o titular da propriedade privada urbana, mas não só para este, também para o proprietário 
público. No entanto, merece destaque um instrumento que não temos noticia de sua utilização, mas de grande relevância urbanística, que contém o intercâmbio entre o interesse privado e o interesse público, numa relação de bilateralidade. Refiro-me ao beneficio concedido ao proprietário que "doar" no todo ou em parte, seu imóvel para o poder publico, em razão de interesse histórico, ambiental, paisagístico, social ou cultural ou para fins de regularização fundiária, de urbanização de áreas ocupadas por população de baixa renda e para construção de habitação de interesse social, de transferir onerosamente, conforme seu interesse, o potencial construtivo do imóvel doado para outrem. Em verdade, não seria propriamente uma doação, mas sim instituto diverso, talvez uma permuta, pois em troca da "doação" recebe o titular do imóvel a faculdade de transferir o seu potencial construtivo para outrem.

Com relação ao que podemos chamar de interesse público direto, isto é, aqueles imóveis de interesse histórico, cultural, artístico, estético, turístico, paisagístico, ambiental (interesses considerados difusos pela Lei 7.347/85) já se conheciam os ônus impostos ao titular, mas sem benefícios, o que já evidenciava o tratamento diversificado da propriedade em relação a tais bens. Agora, ampliou-se a possibilidade de oneração para inclusão do interesse social, mas todos com possibilidade de contrapartida em beneficio do titular. No mesmo sentido para o imóvel de interesse para implantação de equipamentos urbanos e comunitários.

No entanto, com interesse público indireto, concedeu a mesma possibilidade de alienação do potencial construtivo quando o imóvel servir para regularização fundiária de áreas ocupadas por população de baixa renda, identificadas técnica e popularmente como favelas ou com termo mais ameno: comunidades carentes - quando o titular permutar a área com o poder público como acima referido. Todos nós sabemos que as pessoas que compõe ou comporão a futura comunidade, ocupam áreas não utilizadas pelo proprietário privado ou público em razão de seu desinteresse econômico ou outro qualquer (terras que não cumprem qualquer função social), na busca de um teto possível, construindo, como podem suas moradias e também construções para desenvolvimento de atividades econômicas (pequenos comércios e pequenas industrias) e que uma vez adquirida certa estabilidade possessória e agregação de um maior número de ocupantes, praticamente impossível se torna a recuperação pelo titular moroso das terras ocupadas. Repita-se: só foram ocupadas porque estavam abandonadas, sem cumprirem com sua função social, de regra por estarem em áreas de difícil acesso, de pouco interesse como mercadoria de troca ou com fortes restrições ambientais. Então, com esta nova possibilidade, o proprietário que de fato já havia perdido toda utilidade 
que um imóvel urbano lhe proporcionaria, pode permutar este imóvel pelo exercício noutro local do potencial construtivo ceifado pela ocupação popular, dando-lhe uma forma de compensação desde que faça a doação do imóvel para o poder publico, facilitando sobremodo a regularização fundiária, trazendo a comunidade da informalidade para a formalidade proprietária, com todos os benefícios e encargos que tem a propriedade urbana, dando status de proprietário, o que motiva a busca de melhorias para a comunidade, traz respeito e consideração social.

A toda evidencia que não deixa de ser uma solução capitalista para a questão e favorável para o proprietário que não cumpre com a função social da propriedade, solução quase semelhante ao pagamento em dinheiro decorrente da desapropriação-sanção, quando em nosso pensar a propriedade desfuncionalizada em verdade ressente-se de legitimidade constitucional enquanto a posse dos moradores da comunidade atenderia à função social do bem objeto do direito de propriedade.

Percebe-se nitidamente a complexidade acima referida, inerente à propriedade urbana, que de estática, fonte de acumulação da capital passa ser dinâmica, sob pena de perda de legitimidade constitucionalmente conferida ao proprietário. ${ }^{149}$ A propriedade imóvel urbana passa a ter regulação prioritária fora do código civil, quebrando a unidade do sistema inspirado no código e passa ser objeto de planejamento político no interesse geral, visando o desenvolvimento das funções sociais da cidade e à garantia do direito a uma cidade sustentável.

Para a propriedade pública dominical o estatuto, estendeu os mesmos ônus da propriedade privada no que diz respeito ao potencial construtivo, possibilitando também a alienação deste potencial de modo destacado do imóvel, como propriedade nova e autônoma. Regulou a possibilidade da contratação de concessão do direito real de uso de modo coletivo (art. $4^{\circ} \S 2^{\circ}$ da Lei $10.257 / 2001$ ), permitindo assim cumprir um dos objetivos da política urbana, a regularização fundiária e urbanização de áreas ocupadas por população de baixa renda.

Se o imóvel estiver em área urbana ou em determinada região metropolitana que contenha Mata Atlântica, para que o titular do direito edifique ou promova seu

\footnotetext{
149 Para exame da questão da perda de legitimidade da propriedade desfuncionalizada consulte nosso: "A propriedade e a posse". Rio de Janeiro: Editora Lúmen Júris, p. 260-271.
} 
parcelamento, seja por ato voluntário ou em decorrência dos deveres inerentes à função social, deverá observar o contido nos art. 30 e 31 da Lei 11.428/2006.

Portanto, além do interesse privado do titular, além do seu planejamento a respeito do bem objeto de sua titularidade, em razão de estatuto próprio, passa a propriedade urbana, pública ou privada, estar vinculada na sua complexidade às regras próprias do estatuto da cidade. Por certo que tal conclusão não afasta o interesse do titular do direito e nem transforma à propriedade privada em mera concessão administrativa ao particular, mas concede uma liberdade vigiada, de modo que atenda não só aos princípios fundantes do sistema, às regras constitucionais e infra-constitucionais legitimadora de seu direito.

Mui especialmente também cuidou a C.F. das obrigações do proprietário rural, num país de dimensões continentais como o nosso, fixando requisitos simultâneos de legitimação do direito: aproveitamento racional e adequado da propriedade; utilização adequada dos recursos naturais disponíveis e preservação do meio ambiente, observação das leis que regulam as relações de trabalho; exploração que favoreça o bem-estar dos proprietários e dos trabalhadores (art. 186 da C.F. e art. $2^{\circ}$ do Estatuto da Terra). ${ }^{150}$ Os proprietários rurais que não observem qualquer uma das imposições acima estão sujeitos a desapropriação sanção prevista no art. 184 do C.F., uma vez que estão obrigados a cumprirem simultaneamente todos os requisitos, o que efetivamente não tem sido observado pelo governo federal, considerando as freqüentes noticias de proprietários rurais que mantém trabalho em regime de escravidão e propriedades rurais que não cumprem com sua função social. ${ }^{151}$ Neste ponto, a multiplicidade dominial se nota no que diz respeito a natureza e ao objeto (quantificação), considerando a vedação constitucional de desapropriação da pequena e média propriedade rural e a propriedade produtiva (qualitativa) e os reflexos desta

150 Quanto a este ponto colhe-se em julgamento realizado pelo STF em voto do Rel. Min. Celso de Mello: "O acesso à terra, a solução dos conflitos sociais, o aproveitamento racional e adequado do imóvel rural, a utilização apropriada dos recursos naturais disponíveis e a preservação do meio ambiente constituem elementos de realização da função da social da propriedade." (Medida Cautelar na Al n²213-0, julgado em 06.09.2001).

${ }^{151}$ O art. 15 do Estatuto da Terra estabelece: “ A implantação da Reforma Agrária em terras particulares será feita em caráter prioritário, quando se tratar de zonas críticas ou de tensão social.” Essa pratica tem sido adotada pelo governo federal de modo parcimonioso, mas de todo modo encontramos situações analisadas pelo STF em que o Governo pretendia proceder a desapropriação de área rural considerada pelo Governo como improdutiva mas que o Tribunal entendera que não foram observados os requisitos da Lei 8629/93, por violação do devido processo legal, decretando assim a nulidade do decreto desapropriatório, protegendo a propriedade privada em linhas gerais. Tal posicionamento podemos encontrar nos julgamentos a seguir: MS/DF-24547, Rel. Min. Ellen Gracie, julgado em 14.08.2003; MS-23006/PB, Rel. Min Celso de Mello, julgado em 11.06.2003. 
multiplicidade se faz sentir no julgamento do MS-23006/PB pelo STF tendo como relator Min. Celso de Mello, ao analisar a alegação de média propriedade rural (art. 185, I da CF).

Antes mesmo da constituição vigente dar o tratamento diferenciado para as propriedades rural e urbana, a propriedade rural já era objeto de regulação especifica através do Estatuto da Terra (Lei 6.404/67), estabelecendo a multiplicidade dominial em relação ao objeto do direito (propriedade rural, propriedade familiar, minifúndio e latifúndio $-\operatorname{art.~} 4^{\circ}$ ) e em relação ao titular (multiplicidade subjetiva), cuidando da possibilidade de reforma agrária em imóvel público e em imóvel particular, à subordinação aos ditames do estatuto da terra pública rural, das terras devolutas da União, dos Estados e dos Municípios (art. $9^{\circ}$ ), regulando a possibilidade de contrato de exploração temporária da terra para imóvel particular e excepcionalmente para imóvel público (art. 92 e 94), estabelecendo a vedação da manutenção da propriedade rural pública que não seja unicamente para fins de pesquisa, experimentação, demonstração e fomento, visando o desenvolvimento da agricultura, o desenvolvimento de programas de colonização ou fins educativos de assistência técnica e de readaptação, e fora dessas hipóteses, somente se admitirá a propriedade pública rural em caráter transitório, desde que não haja viabilidade de transferi-los para a propriedade privada ( $\operatorname{art} .10$ e seu $\S 1^{\circ}$ ). O uso da propriedade particular rural deverá atender à sua função social e seu uso está condicionado ao bem-estar coletivo (art. 12), dentre outras particularidades específicas da propriedade rural, evidenciando a distinção estatutária com a propriedade urbana.

Também em relação à multiplicidade do objeto do direito, o Código Florestal identifica que tipo de imóvel considera como pequena propriedade rural e a posse rural familiar (art. $1^{\circ} \S 2^{\circ}$ ). Considera como reserva legal a área localizada no interior de uma propriedade ou posse rural, excetuada a de preservação permanente, necessária ao uso sustentável dos recursos naturais, à conservação e reabilitação dos processos ecológicos, à conservação da biodiversidade e ao abrigo e proteção de fauna e flora nativas (art. $1^{\circ} \S 2^{\circ}$ item III).

Se na área objeto de sua propriedade for possível a exploração mineral mas, localizando-se o imóvel em área de Mata Atlântica, a atividade, que em principio resultaria naturalmente da titularidade, contida no direito de usar, gozar e fruir do bem, tal exploração só será possível com licenciamento ambiental, condicionado à apresentação de Estudo Prévio de Impacto Ambiental e Relatório de Impacto Ambiental, além da adoção de medida compensatória que inclua a recuperação de área equivalente à área do empreendimento, com 
as mesmas características ecológicas, nos termos do art. 32 da Lei 11.428/2006. As normas específicas para este tipo de propriedade evidenciam ainda mais a multiplicidade dominial.

As terras rurais, uma vez desapropriadas para fins de reforma agrária, ${ }^{152}$ deverão ser entregues aos beneficiários com observância além das regras do Estatuto da Terra mas também do Código Florestal (art. $8^{\circ}$ ), certamente com um programa de infra-estrutura e orientação dos órgãos públicos competentes conforme previsão do Estatuto da Terra, para que não ocorra, como normalmente acontece nas tentativas frustradas do passado, em que os beneficiários logo que tomam posse do imóvel retiram a madeira vendendo-as como lenha para obterem recursos para o plantio e depois acabam por "venderem", a despeito da proibição (art. 189 da C.F.) para pessoas abastadas que vão formando grandes sítios de lazer ou remembrando as áreas transformando em novas fazendas privadas. O repasse para o colono é isento de impostos federais, estaduais e municipais ( $\$ 5^{\circ}$ do art. 184).

Com relação às terras públicas rurais (multiplicidade em razão da natureza do objeto e de seu titular) além das referencias acima realizadas, sua utilização deverá ser compatibilizada com a política agrícola e com o plano nacional de reforma agrária. $\mathrm{O}$ mesmo procedimento deverá ser adotado em relação às terras devolutas (art. 188 da $\mathrm{CF}$ ), ${ }^{153}$ estas que

152 Considera-se Reforma Agrária o conjunto de medidas que visem a promover melhor distribuição da terra, mediante modificações no regime de sua posse e uso, a fim de atender aos princípios de justiça social e ao aumento de produtividade (art. $1^{\circ} \S 1^{\circ}$ do Estatuto da Terra).

153 Com relação às terras devolutas a situação pode ser examinada do seguinte modo: até 1850 , antes de entrar em vigor da Lei de Terras $n^{\circ} 601$, nossas terras podiam ser classificadas: a)terras particulares: as submetidas ao domínio de um particular, em virtude de titulo legítimo concedido pela Coroa, em razão de ter cumprido com suas obrigações (obrigações positivas já presentes no limiar do nascimento de nossa propriedade, evidenciado a complexidade do dominio); b) terras públicas, que comportavam subdivisões: $1^{a}$ ) as pertencentes à Nação, às Provinciais e aos Municípios: $2^{a}$ ) as

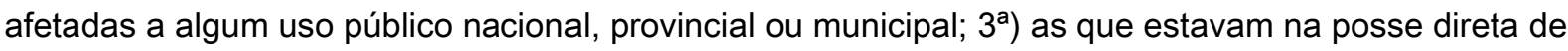
particulares, em razão de concessões, mas que estavam incursas em comisso, por descumprimento das obrigações positivas acima referidas: medição e cultura e por falta de confirmação; $4^{\text {a }}$ ) aquelas que se achavam na posse direta de particulares como posse autônoma, em razão da ocupação, sem titulo que as justificasse; $5^{\mathrm{a}}$ ) aquelas cujo dominio útil fora conferido a um particular; $6^{\text {a) }}$ as terras desocupadas, isto é, não estavam na posse de ninguém. (cf. Linhares de Lacerda, Tratado das Terras..., vol. 1,ob cit., p. 126; Paulo Garcia. Terras Devolutas. Belo Horizonte: Edição da Livraria Oscar Nicolai, 1958, p. 29). Com a edição da Lei 601 conseguiu-se reduzir este quadro em tres categorias bem definidas: a) terras particulares; b)terras públicas aplicadas a algum uso nacional, 
tem sido ocupadas e objeto de grilagem constante em razão do descontrole do governo não só quanto à sua existência mas também em relação ao exercício da posse sobre elas, o que de certo modo legitima a exploração da posse com função social, mas não legitima para fins de especulação e apropriação indevidas como normalmente ocorre.

Há também em relação às propriedades rurais uma limitação para alienação (direito senão o mais um dos mais importantes da titularidade) ou arrendamento para pessoa física ou jurídica estrangeira (art. 190 da C.F.).

Na propriedade em geral as alterações introduzidas pelo novo código civil na caracterização do conteúdo do direito, com a ampliação dos deveres do titular em prol de interesses não proprietários, consubstanciam a caracterização da noção plural das propriedades. Esta noção se extrai da regra contida no $\S 1^{\circ}$ do art. 1228 do código civil ao fixar que o direito de propriedade deve (dever, obrigação) ser exercido em consonância com suas finalidades econômicas e sociais e de modo que sejam preservados, de conformidade com o estabelecido em lei especial, a flora e a fauna, as belezas naturais, o equilíbrio ecológico e o patrimônio histórico e artístico, bem como evitada a poluição do ar e das águas.

A despeito de não perder a característica de um direito subjetivo dos mais representativos no direito privado, aos deveres acima acrescentou a proibição (que não deixa de ser um dever negativo) de atos emulativos, que na visão oitocentista estariam compreendidos na gama de poderes conferidos ao titular ( $\$ 2^{\circ}$ do art. 1228 do $\left.\mathrm{CC} / 02\right)$, afastando a visão egoísta de inerência tradicional do direito de propriedade, para privilegiar uma visão solidarista e humanizada. Em verdade na sistemática do atual código todo o direito deve ser exercido nos limites impostos por seu fim econômico ou social, sob pena de descambar em ilicitude, em abuso do direito conforme previsão do art. 187 do CC/2002. Aliás, a doutrina do abuso do direito de propriedade pode ser considerada como uma precursora da doutrina da função social da propriedade.

Ampliou o novo código as possibilidades de perda da propriedade que não cumprir com sua função social e econômica, reduzindo consideravelmente em beneficio do possuidor que cumprir uma função social com sua posse, os prazos de aquisição por usucapião e ainda através de uma forma especial, não bem definida pela doutrina ${ }^{154}$ de

provincial ou municipal e c) terras devolutas. $O$ art. $3^{\circ}$ da Lei acima referida cuidou de especificar cada uma destas hipóteses.

${ }^{154}$ A questão da natureza jurídica desta forma de perda do direito é controvertida na doutrina, tendo a polêmica começado com um artigo publicado no jornal "O Estado de S. Paulo" em 21.12.72 onde o professor Caio Mário, 
privação da propriedade que descumpre com sua função social em favor daqueles que cumprem nela uma função social com obras e serviços considerados pelo juiz de interesse social e econômico relevante ( $\S 4^{\circ}$ e $5^{\circ}$ do art. 1228 do CC).

Por outro lado, ao que se vê do Estatuto da Cidade e do Código Civil em vigor a propriedade como direito humano de caráter fundamental se humaniza para proteção de núcleos de interesses fora do(s) interesse(s) privado(s) do titular, sem afastar este, se exercido em desconformidade com a ordem jurídica. Atende assim um vetor fundamental de nosso sistema, qual seja a dignidade da pessoa humana, abstraindo-se do ter para valorizar o ser, não só do titular do direito, conferindo-lhe a proteção do sistema na hipótese de violação do seu direito quando reste evidenciado no caso concreto que o titular cumpre com sua função social, mas também a proteção de interesses outros, tão ou mais importantes para o grupo social do que o interesse do titular. Esse vetor dignidade, ao mesmo tempo em que protege limita o direito de propriedade em virtude de outros direitos que do princípio da dignidade emanam e que servem para garantir o bem-estar social do outro, conforme leciona Ralpho Filho. ${ }^{155}$ Nas palavras de Newman Debs: não se aboliu o direito de propriedade, fundamento de nossa sociedade capitalista, tão somente abriu-se espaço para implantação de novas regras que vivificam, no território dos direitos reais, o axioma constitucional da dignidade de todas as pessoas humanas. Dito de outro modo: "buscou o legislador dignificar o direito de

chamava atenção para o dispositivo do então projeto, afirmando ele ser "inconstitucional"- porque entendia que a desapropriação está sujeita a cânones constitucionais, não sendo possível o legislador ordinário criar mais um caso de desapropriação e muito menos sem "prévia" indenização."Irrealizável" - porque não ficou definido quem pagaria a indenização: os ocupantes certamente que não, pois não terão recursos para tal. O Estado, não pode ser compelido a desapropriar, pois compete ao executivo e não ao judiciário fixar a orientação econômica do governo. "Inconveniente" - porque fixa uma modalidade de desapropriação sem controle do executivo e sem fiscalização do legislativo apreciada pelo juiz, cujas convicções podem ser deformadas por injunções que sua própria atividade jurisdicional não tem como coibir. Respondendo a crítica Miguel Reale no mesmo jornal em 05.01.73, assinala que trata-se de uma hipótese de desapropriação indireta, como já acontece em nosso sistema em muitas situações. Antes, porém, o pranteado mestre paulista no oficio que encaminhava o então anteprojeto ao Min. da Justiça, afirmara: "nessa hipótese, abre-se, nos domínios do Direito, um via nova de desapropriação, que se não deve considerar prerrogativa exclusiva dos Poderes Executivo e ou Legislativo." (Cf. anteprojeto do C. Civil, Ministério da Justiça, Com. de Est. Legislativos. 1972, p.25). Sobre as diversas opiniões a respeito consulte nosso artigo "Direito das Coisas no Novo Código Civil", in Suplemento Amaerj Especial, Amaerj Noticias, $\mathrm{n}^{\mathrm{o}}$ 14, nov.2003. Veja-se também interessante estudo realizado por Camilo Barbosa e Rodolfo Pamplona, intitulado "Compreendendo os novos limites à propriedade: uma análise do art. 1228 do Código Civil Brasileiro", em que os autores fazem uma digressão aprofundada sobre o assunto para considerarem como "uma modalidade desapropriatória especial". (BARBOSA, Camilo de Lelis C. e FILHO, Rodolfo Pamplona, in Revista Júris Plenum, ano III, n 14, março de 2007, p. 17-34.

155 FILHO, Ralpho Waldo de Barros Monteiro. Função social da propriedade: conteúdo e diretrizes para sua compreensão. Revista Forense. Vol. 397 p. 291. 
propriedade, deixando de considerá-lo intocável, destinado única e exclusivamente a atender os interesses de seu titular." 156

A visão socializante do direito, antes mesmo da C.F. estabelecer como objetivo fundamental da República a construção de uma sociedade justa e solidária (art. $3^{\circ}$ inc. I) foi segundo Miguel Reale, uma das diretrizes fundamentais considerada pela comissão elaboradora do C.C. em vigor, que tem o sentido de humanização do Direito, colocando as regras jurídicas num plano de vivência social. ${ }^{157}$

Nem se diga que o legislador infraconstitucional estaria impedido em razão da garantia constitucional e da natureza fundamental do direito de propriedade de regulá-lo de forma ampla, haja vista a atribuição ao legislador ordinário de um poder que lhe permite estabelecer restrições, definindo a amplitude, a conformação, o conteúdo do próprio direito. Neste sentido a lição de Gilmar F. Mendes, que ainda assinala:

\begin{abstract}
Como essa categoria de direito fundamental, que se apresenta, a um só tempo, como garantia institucional e como direito subjetivo, confia ao legislador, primordialmente, o mister de definir, em essência, o próprio conteúdo do direito regulado, fala-se, nesses casos, de regulação ou de conformação (Regelung oder Ausgestaltung) em lugar de restrição (Beschränkung).

É que as normas legais relativas a esses institutos não se destinam, precipuamente, a estabelecer restrições. Elas cumprem antes relevante e indispensável função como normas de concretização ou de conformação desses directos (...)

Embora, teoricamente, não se possa caracterizar toda e qualquer disciplina normativa desses institutos como restrição, não há como deixar de reconhecer que o legislador pode, no uso de seu poder de conformação, redesenhar determinado instituto, com sérias e, não raras vezes, gravosas conseqüências para o titular do direito. ${ }^{158}$
\end{abstract}

Na seara constitucional ainda encontramos a limitação quanto à alienação de terras devolutas ou terras arrecadadas pelos Estados através de ações discriminatórias, que forem necessários à proteção dos ecossistemas naturais ( $§ 5^{\circ}$ do art. 225 da C.F.) e as terras que abriguem a Floresta Amazônica, a Mata Atlântica, a Serra do Mar, o Pantanal MatoGrossense e a Zona Costeira, suportam severas restrições de utilização, inclusive com relação aos recursos naturais, em favor das futuras gerações, diante da necessidade de assegurarem a

156 DEBS, Newman. Aquisição e Perda da Propriedade - usucapião: roupagem dada pelo novo Código Civil . RT 811-24.

157 REALE, Miguel. O Projeto de Código Civil. São Paulo: Saraiva Ed., 1986, p. 9.

158 MENDES, Gilmar Ferreira. A Reforma Monetária de 1990 - Problemática Jurídica da Chamada "Retenção dos Ativos Financeiros. Revista de Inf. Legislativa Brasília n. 112 out/dez. 1991, p. 257, 259/260 - grifou-se. 
preservação do meio ambiente ( $\$ 4^{\circ}$ do art. 225 da C.F.). Em relação a estas últimas áreas, segundo registro de Francisco Loureiro, a falta de um correto desenvolvimento doutrinário da teoria da função social da propriedade e do direito ao meio ambiente salutar, "como elemento de ponderação não-proprietário", levaram os tribunais a concederem indenizações por limites que consideravam externos ao domínio, isto porque, não se fez uma "análise sistemática" da relação de propriedade, "cuja própria estrutura está recheada de deveres e limites internos", até que numa guinada de correção passaram a encarar a situação proprietária de modo diferenciado, em razão da peculiaridade do bem objeto da titularlização. ${ }^{159}$

Por certo que a lógica dominical clássica não atenderia de modo algum a estes interesses dignos de proteção constitucional, já que centrada no interesse exclusivo do titular do direito, numa lógica liberal inaceitável para a propriedade dos tempos atuais. Essa era a lógica inspiradora de nosso código civil de 1916 e de tantos outros códigos oriundos do mesmo movimento de codificação oitocentista.

Também não se pode olvidar que a despeito de tais disposições específicas, indicando estatutos diversos conforme a natureza e utilidade do bem, que há uma regra geral, inserida no capítulo das garantias individuais que, por sua vez, se vincula aos princípios fundantes de nossa República, contidos nos artigos $1^{\circ}$ e $3^{\circ}$ da Constituição, daí porque afirmar tratar-se de um mínimo conteúdo, que é maximizado pelos princípios constitucionais impositivos, para abraçar a classificação de Canotilho. ${ }^{160}$

Do que foi dito, pode-se dizer que os vários regimes da propriedade comportam distinções qualitativas e quantitativas. Na qualidade pode-se indicar como ex., os regimes jurídicos diversos entre os bens de produção e os bens de consumo, entre empresa nacional e empresa estrangeira, entre propriedade pessoal e propriedade comunitária, propriedade cooperativa. Quantitativas no que toca, por ex., as distinções entre a grande, pequena e micro empresa, entre a grande e pequena propriedade rural. ${ }^{161}$

Daí afirmar Perlingieri que hoje não há um, mas vários institutos da propriedade, cada um deles regido por um complexo de normas singulares. ${ }^{162}$

159 LOUREIRO, Francisco E. A propriedade ... ob. cit., p. 168. Veja-se a propósito REsp. 30.835-SP, Rel. Min. Humberto G. de Barros; REsp. $n^{\circ}$ 123.835-SP, Rel. Min. Milton Luiz Pereira; REsp. $n^{\circ}$ 162.547, Rel. Min. Franciulli Netto.

160 CANOTILHO, José J. Gomes. Direito Constitucional... ob. cit. p. 179.

161 LOUREIRO, Eduardo Francisco. A Propriedade como Relação Jurídica Complexa, ob. cit. p. 59. 162 PERLINGIERI, Pietro. Introduzione Alla Problematica Della Proprietà, ob. cit. p. 148. 


\section{6 - Conclusão.}

Sempre que se analisa um instituto jurídico há necessidade de confronto entre características passadas do instituto, conforme registros históricos e a visão que se tem no momento de análise, procurando demonstrar conexão ou diversidade no desenvolvimento do instituto.

No entanto, não se pode perder de vista que os fenômenos sociais objeto de exame variam em cada tempo, por força de circunstancias peculiares e a rigor nada há de definitivo, a despeito da segurança jurídica que se espera de seus institutos, sempre haverá lugar a uma adequação à cada momento histórico e cultural que se esteja vivendo, servindo o exame das experiências dos antepassados como formas de aperfeiçoamento de cada instituto, para melhor servir ao homem.

Assim também ocorre com a propriedade, instituto que varia de perfil conforme a época, nação e regime político e social preponderante em cada tempo, como procurou-se demonstrar na variação da propriedade individual com unidade conceitual até a queda do império romano, passando para a propriedade dividida na idade média, com pluralidade conceitual e o retorno ao conceito unitário, centrado no movimento codificatório oitocentista, a partir do código civil francês, tornando legalmente unitário o conceito e por fim a demonstração da idéia pluralista como a mais adequada à propriedade moderna.

No entanto, o reconhecimento da multiplicidade dominial, aspecto central deste ensaio, parece contrapor-se a um conceito do direito de propriedade, com foros de generalidade. Contudo, quanto a este aspecto Rodotá assinala que não deixou de existir um conteúdo essencial ou mínimo da propriedade, identificado pela aptidão natural ou histórica de cada bem para ser objeto de utilização econômica. ${ }^{163}$ A existência de referencias unitárias no sistema atual não entra em contradição com a comprovação da diversidade de propriedades. $^{164}$

Não se trata da multiplicação de noções com objetivo de substituir o conceito unitário. Este não se esvai, torna-se apenas um dos muitos elementos que devem ser levados

\footnotetext{
163 RODOTÁ, Stefano, El terrible derecho..., op cit., p. 64. 164 Ibidem, p. 55.
} 
em conta, variando de importância conforme o setor proprietário que se esteja examinando. A pluralidade de propriedades, pressupõe um direito comum de propriedade como categoria genérica. ${ }^{165}$ Seu "peso sistemático, é redimensionado, sua carga realista é retomada, renovando-se, desse modo, sua condição e vitalidade como instituto central."166

A propriedade continua sendo uma espécie de direito subjetivo do titular, com função primária de satisfação de suas necessidades essenciais e de sua família. Estes bens primários constituem, na visão de Rodotá: “el nuevo núcleo duro del derecho de propriedad". ${ }^{167}$ É o principio da dignidade da pessoa humana que em última "ratio" para a tutela de um patrimônio mínimo, em outras palavras, um mínimo de propriedade, de acesso aos bens de modo assegurar sobrevivência digna, com acentuou o STF na lavra do Min. Celso de Mello ao afirmar que "não se pode deixar de reconhecer, sob a perspectiva da questão fundiária, a importância que - em área socialmente tão sensível - assumem a formulação e a implementação de uma política pública que viabilize o acesso dos despossuídos à propriedade da terra, em ordem a permitir a participação de todos na justa distribuição da riqueza nacional, para que, erradicadas a pobreza e a marginalização, seja possível construir uma sociedade justa e livre, fundada em bases solidárias"168.

\section{7 - Referências}

ALMEIDA, Francisco de P. Lacerda de. Direito das cousas. Rio de Janeiro: Ribeiro dos Santos, 1908.

ALVES, José Carlos M.. Direito Romano. 9. edição. Vol. I. Rio de Janeiro: Forense, 1995.

165 VARELA, Laura B. e LUDWIG, Marcos de C. Da Propriedade às Propriedades: Função Social e Reconstrução de um Direito. p. 771.

166 Ibidem, p. 771.

167 RODOTÁ, Stefano. El terrible..ob cit., p. 35-36.

168 Supremo Tribunal Federal. Medida Cautelar em Ação Direta de Inconstitucionalidade $n^{\circ} 2.213-$ Distrito Federal. Rel. Min. Celso de Mello. 06.09.2001. 
ALVIM, Arruda. Breves Anotações para uma Teoria Geral dos Direitos Reais, in Posse e Propriedade. Org. Yussef S. Cahali. São Paulo: Saraiva, 1987.

AMARAL, Francisco. Direito Civil. Introdução. Rio de Janeiro: Forense, 1991.

ANDRADE, Manuel A. Domingues. Ensaio sobre a Teoria da Interpretação das Leis. 3. ed., Coimbra: Armênio Amado, 1978.

Teoria Geral da Relação Jurídica. Vol 1. Coimbra: Almedina, 1983.

ARISTÓTELES. A Política. Trad. Nestor Silveira Chaves. 6. ed. São Paulo: Atena Editora, 1960.

ARONNE, Ricardo. Propriedade e Domínio. Reexame Sistemático das Noções Nucleares de Direitos Reais. Rio de Janeiro: Renovar, 1999.

ASCENSÃO, José de Oliveira. Direito Civil. Reais. 4. ed., Coimbra: Coimbra, 1987.

BARBOSA, Camilo de Lelis C. e FILHO, Rodolfo Pamplona. Compreendendo os novos limites à propriedade: uma análise do art. 1228 do Código Civil Brasileiro. Revista Juris Plenum, ano III, nº 14, março de 2007, p. 17-34.

BASTOS, Celso R. A função social como limite constitucional ao D. de Propriedade. Revista de Dir. Constitucional e Ciência Política. n. 6, vol. 4, 1988.

BASTOS, Celso R. e MARTINS, Ives Gandra. Comentários à Constituição do Brasil. São Paulo: Saraiva, 1989.

BESSONE, Darcy. Direitos Reais. São Paulo: Saraiva, 1988.

BEVILAQUA, Clovis. Direito das Coisas. 4. Ed., vol. I. Rio de Janeiro: Forense, 1956. Teoria Geral, 2. ed., São Paulo-Rio de Janeiro: Livraria Francisco Alves, 1929.

O Conceito de Propriedade. Rev. de Direito Público. Vol. II. Rio de Janeiro: Freitas Bastos, 1940, p.6 
BEZERRA, Raimundo Falcão. A função social da propriedade. São Paulo: RDA, vol. $55 / 56$.

BOBBIO, Norberto. Direito e Estado no Pensamento de Emanuel Kant. 2. ed. Brasília: Universidade de Brasília, 1992.

BURNS, Edward Mcnall. História da Civilização Ocidental. $1^{\circ}$ vol. Porto Alegre: Globo, 1980.

História da Civilização Ocidental. $2^{\circ}$ vol. Porto Alegre: Globo, 1980.

CALMON, Pedro. História do Brasil. v. VI. Rio de Janeiro: José Olímpio, 1959.

CANOTILHO, José J. Gomes. Direito Constitucional. 5. ed. Coimbra: Almedina, 1992.

CHAMOUN, Ebert. Instituições de Direito Romano, 3. ed., Rio de Janeiro: Forense, 1957.

COGLIOLO, Pietro. Philosofia de Direito Privado. Bahia: Empreza Editorial, 1898.

COULANGES, Fustel. A cidade antiga: estudos sobre o culto, o direito, as instituições da Grécia e de Roma. Trad. Fernando de Aguiar, 9. ed. Lisboa: Livraria Clássica Editora, 1957.

DEBS, Newman de Faria. Aquisição e perda da propriedade. Usucapião. Roupagem dada pelo novo Código Civil. Revista dos Tribunais, São Paulo, v. 92 , n.811, p. 24-34, maio 2003.

DUGUIT. Leon. Las Transformaciones genereles del Derecho privado desde el Código de Napoléon. 2. ed. Madrid: Francisco Beltran, 1920.

ENGELS, Friedrich. A Origem da Família, da Propriedade Privada e do Estado. 3. ed. São Paulo: Global, 1984.

ENGISH, Karl. Introdução ao pensamento jurídico. 6. ed. Lisboa: Calouste Gulbenkian, 1988. 
ESPÍNOLA, Eduardo. Posse-Propriedade, Compropriedade ou Condomínio, Direitos Autorais. Rio de Janeiro: Conquista, 1956.

FACHIN, Luiz E. A Função Social da Posse e a Propriedade Contemporânea. Porto Alegre: Sergio A Fabris, 1988.

FERRARA, Francesco. Interpretação e Aplicação das Leis. 3. ed. Coimbra: Armênio Amado Editor, 1978.

FILHO, Ralpho Waldo de Barros Monteiro. Função social da propriedade: conteúdo e diretrizes para sua compreensão. Rio de Janeiro: Revista Forense. Vol. 397, p. 283.

FISCHBACH, Oskar Georg. Teoria General del Estado. 4. ed. Barcelona: Editorial Labor, 1949.

FULGÊNGIO, Tito. Direito de vizinhança. Rio de Janeiro: Forense, 1959.

GAMBARO, Antonio. Jus Aedificand e Nozonie Civilistica della Proprieta. Giuffrè Editore, 1975.

GARCIA, Paulo. Terras Devolutas. Belo Horizonte: Livraria Oscar Nicolai, 1958.

GASSEN, Valcir. A Natureza Histórica da Instituição do Direito de Propriedade. In Fundamentos de História do Direito, Org. Antonio Carlos Wolkmer, 2. ed. Belo Horizonte: Del Rey, 2006.

GILISSEN, John. Introdução Histórica ao Direito. Lisboa: Calouste Gulbenkian, 1979. GOMES, Orlando. Direitos reais. 19. ed. Rio de Janeiro: Forense, 2004.

GOMES, Orlando. Novas Dimensões da Propriedade Privada. v. 59, n. 411, p. 9-14, jan., 1970.

GONÇALVES, Luiz da Cunha. Da propriedade e da posse. Lisboa: Ática, 1952.

GONÇALVES, Luiz da Cunha. Tratado de Direito Civil em Comentário ao Código Civil Portugues. 2. ed. vol. XI. São Paulo: Max Limonad, s/d. 
GROPALLI, Alessandro. Introdução ao Estudo do Direito. Coimbra: Coimbra, 1974.

GROSSI, Paolo. História da Propriedade e outros ensaios. Rio de Janeiro: Renovar, 2006.

GROSSI, Paolo. La propiedad y las propiedades. Un Análisis histórico. 1. ed. Madrid: Editorial Civitas, 1992.

HOLANDA, Sergio Buarque. A Época Colonial. Tomo I, vol. 2. São Paulo: Difusão Européia do Livro, 1960.

IHERING, Rudolf von. A Finalidade do Direito. Tomo I. São Paulo: Bookseller, 2002.

JÁLFINA, Raísa. El Derecho de Propriedad Del Estado em la URSS. Moscou: Editorial Progresso, 1981.

JAMBRENGHI, Vicenzo Caputi. Proprietà Privata (Disciplina Amministrativa) in Digesto delle Discipline Pubblicistiche. v. XII, Utet., 4· ed, 1987.

JUNIOR, J. Cretella. Curso de Direito Romano. 11. ed. Rio de Janeiro: Forense, 1987.

JUSTINIANO. Instituições de Justiniano. Livro 1 T. F. I. n.1, Curitiba: Tribunais do Brasil Editora,1979.

KELSEN, Hans. Teoria Pura do Direito. Rio de Janeiro: Martins Fontes, 1985.

$\mathrm{KICH}$, Bruno C. A Propriedade na Ordem Jurídica, Econômica e Ideológica. Porto Alegre: Sergio Antonio Fabris Editor, 2004.

LACERDA, M.Linhares de. Tratado das Terras do Brasil. Vol 1. Rio de Janeiro: Editora Alba, 1960.

LARENZ, Karl. La Filosofia Contemporânea del Derecho y del Estado. Madrid: Revista de Derecho Privado, 1942.

LIRA, Ricardo Pereira. Elementos de Direito Urbanístico. Rio de Janeiro: Renovar, 1997. 
LOPES, Miguel Maria de Serpa. Curso de Direito Civil. Direito das Coisas: Princípios Gerais, Posse, Dominio e Propriedade Imóvel. 2. ed., vol. VI, São Paulo/Rio de Janeiro: Livraria Freitas Bastos, 1962.

LOUREIRO, Francisco E. A Propriedade como Relação Jurídica Complexa. Rio de Janeiro: Renovar, 2003.

MALMESBURY, Thomas Hobbes. Leviatã. São Paulo: Editor Victor Civita, 1983.

MÁYNEZ, Eduardo García. Introduccion al Estúdio del Derecho. 4. ed. México: Editorial Porrua, 1951.

MAZZONI. Emidio Pacifici. Instituzioni di Diritto Civile Italiano. 3. edição. vol. III. Firenze Ed., Eugenio e Filippo Cammelli. 1884.

MENDES, Gilmar Ferreira. A Reforma Monetária de 1990 - Problemática Jurídica da Chamada "Retenção dos Ativos Financeiros. Revista de Inf. Legislativa Brasília n. 112 out/dez. 1991.

MONTEIRO, Washington de B., Curso de Direito Civil, $3^{\circ}$ v., 37. ed, São Paulo: Saraiva, 2003.

OLIVEIRA, J.M. Leoni Lopes de Oliveira. Introdução ao Direito. 2. ed. Rio de Janeiro: Lumen Juris, 2006.

PAPANO, Jose R., KIPER, Cláudio M., DILLON, Gregório A., CAUSSE, Jorge R. Derechos Reales. Tomo I. Buenos Aires: Ediciones Depalma, 1993.

PASUKANIS, Eugeny B. A Teoria Geral do Direito e o Marxismo. Rio de Janeiro: Renovar, 1989.

PEREIRA, Caio Mário da S. Instituições de Direito Civil. Direitos Reais. v. IV, Rio Janeiro: Forense, 2003. Instituições de D. Civil. 9. edição. vol. Ol. Rio de Janeiro: Forense, 2003.

PEREIRA, Lafayette R. Direito das Coisas. Vol I. Brasília: Senado Federal, 2004. 
PEREIRA, Virgílio de Sá. Direito das Coisas. vol. VIII. Jacintho Ribeiro dos Santos, 1924.

PEREIRA, J.O de Lima. Da Propriedade no Brasil. São Paulo: Casa Duprat, 1932.

PERLINGIERI, Pietro. Introduzione Alla Problematica Della Proprietà. Camerino: Jovene Editore, 1970.

Perfis do Direito Civil. Introdução ao Direito Civil Constitucional. Rio de Janeiro: Renovar, 1997.

PEZZELLA, Maria Cristina Cereser. Propriedade Privada no Direito Romano. Porto Alegre: Sergio A. Fabris Editor, 1998.

PICAZO, Luiz Díez. Prólogo. In: RODOTÁ, Stefano. El terrible derecho : estudios sobre la propiedad privada. Madrid: Civitas, 1986.

PINTO, Carlos Alberto da M. Teoria Geral do Direito Civil. Coimbra: Coimbra, 1980.

PIPES, Richard. Propriedade e Liberdade. Rio de Janeiro: Record, 2001.

POSADA, Adolfo. Estúdio preliminar. La Declaración de Los Derechos del Hombre y Del Ciudadano. Madrid: Libreria General de Victoriano Suárez, 1908.

PROUDHON, Pedro Jose. Que es la Propriedad?. Buenos Aires: Editorial Proyección S.R.L. 1970.

PUGLIATTI, Salvatore. La Proprietá Nel Nuovo Diritto, Milano: Giuffrè Editore, 1964.

RADBRUCH, Gustav. Filosofia do Direito. 6. ed. Coimbra: Armênio Amado Editor, Sucessor, 1979.

RAWLS, John. Uma Teoria da Justiça. São Paulo: Martins Fontes, 1997.

REALE, Miguel. O Projeto de Código Civil. São Paulo: Saraiva, 1986.

RIBAS, Antonio Joaquim. Da Posse e das Ações Possessórias. São Paulo: Ed. Miguel Melillo \& Cia,, s/d.

RIBEIRO, João. Historia do Brasil. 16. ed. Rio de Janeiro: Livraria São José, 1957. 
RIZZARDO, Arnaldo. Direito das Coisas. 2. ed. Rio de Janeiro: Forense, 2006.

RODOTÁ, Stefano. El terrible derecho: estúdios sobre la propriedad privada. Trad. Luiz Díez-Picazo. Madri: Civitas, 1986.

RODRIGUES, Silvio. Direito Civil. Direito das Coisas. 28. ed., vol. 5. São Paulo: Saraiva, 2003.

ROMANO, Santi. Fragmentos de un Diccionario Jurídico. Buenos Aires: Ediciones Jurídicas Europa-América, 1964.

ROUSSEAU, Jean-J. O Contrato Social. Porto: Publicações Europa-América, 1976.

ROUSSEAU, Jean-Jacques. Discurso sobre a Origem da Desigualdade. Trad. de Maria Lacerda de Moura. Rio de Janeiro: Athena Editora, s/d,.

RUGGIERO, Roberto de. Instituições do Direito Civil. Vol. 2. São Paulo: Saraiva, 1972.

SALDANHA, António Vasconcelos. As capitanias do Brasil. Comissão Nacional para as Comemorações dos Descobrimentos Portugueses. Lisboa, 2001.

SILVA, José Afonso da. Direito Urbanístico Brasileiro. 2. ed. São Paulo: Malheiros, 1995.

SOLON, Ari Marcelo. A função do conceito de direito subjetivo de propriedade. Dissertação de Mestrado apresentado na USP. São Paulo, 1987.

SOUZA, Marnoco e. História das Instituições do Direito Romano, Penínsular e Portugues. Coimbra: Imprensa de Universidade, 1904.

TEPEDINO, Gustavo. 1989. A nova propriedade (o seu conteúdo mínimo, entre o código civil, a legislação ordinária e a constituição). Revista Forense, ano 85, v. 306, abr./maio/jun.1989, p. 73-78.

Gustavo. A Tutela da Propriedade Privada na Ordem Constitucional. Revista da Faculdade de Direito da UERJ, vol. 1, 1993. 
Gustavo. Contornos Constitucionais da Propriedade Privada. In Temas de Direito Civil. Rio de Janeiro: Renovar, 1999.

TRABUCCHI, Alberto. Istituzioni di Diritto Civile. Padova: Casa Editrice Dott Antonio Milani, 1978.

VARELA, Laura B. e LUDWIG, Marcos de C. Da Propriedade às Propriedades: Função Social e Reconstrução de um Direito. In $A$ Reconstrução do Direito Privado. Org. Judith Martins-Costa. Editora Revista dos Tribunais, 2002.

VILLEY, Michel. Estúdios em torno da la nocion de Derecho Subjetivo. Ediciones Universitárias de Valparaiso. Universidad Católica de Valparaiso, 1976.

WOLFF, Martín. Derecho de Cosas. Trad. José Puig Brutau, 2. ed, Barcelona: Bosch, Casa Editorial, s/d.

Jornais

ALENCASTRO, Catarina. Jobim recorre à AGU por terras de Alcântara. O Globo.Rio de Janeiro. 04.02.2009. O País, p. 10.

GALDO, Rafael. Índios dizem que vão resistir em Camboinhas. $O$ Globo. 08.02.2009. Niterói, p. 4. 